\title{
norden
}

\section{Market efficiency in Nordic and Baltic Stock Exchanges - Final report}

TemaNord 2004:534 


\section{Market efficiency in Nordic and Baltic Stock Exchanges - Final report}

TemaNord 2004:534

(C) Nordic Council of Ministers, Copenhagen 2004

ISBN 92-893-1028-6

ISSN 0908-6692

Nordic Council of Ministers

Store Strandstræde 18

DK-1255 Copenhagen K

Phone (+45) 33960200

Fax (+45) 33960202
Nordic Council

Store Strandstræde 18

DK-1255 Copenhagen K

Phone (+45) 33960400

Fax $\quad(+45) 33111870$

www.norden.org

\section{The Nordic Co-operation on Economy and Finance}

Nordic co-operation in the area of economy and finance includes consultations on stabilisation policies, studies and discussion of strategies for structural policies, evaluation of adjustment policies for the European economic integration process as well as support to the economic transformation process in Eastern- and Central Europe. The work in this area is governed by the Ministers of Finance and Economy and they are assisted by a Nordic Committee of Senior Government Officials.

\section{The Nordic Council of Ministers}

was established in 1971. It submits proposals on co-operation between the governments of the five Nordic countries to the Nordic Council, implements the Council's recommendations and reports on results, while directing the work carried out in the targeted areas. The Prime Ministers of the five Nordic countries assume overall responsibility for the co-operation measures, which are co-ordinated by the ministers for co-operation and the Nordic Co-operation committee. The composition of the Council of Ministers varies, depending on the nature of the issue to be treated.

\section{The Nordic Council}

was formed in 1952 to promote co-operation between the parliaments and governments of Denmark, Iceland, Norway and Sweden. Finland joined in 1955. At the sessions held by the Council, representatives from the Faroe Islands and Greenland form part of the Danish delegation, while Åland is represented on the Finnish delegation. The Council consists of 87 elected members - all of whom are members of parliament. The Nordic Council takes initiatives, acts in a consultative capacity and monitors co-operation measures. The Council operates via its institutions: the Plenary Assembly, the Presidium and standing committees. 


\section{Content}

Efficiency in Nordic and Baltic Financial Markets ............................... 7

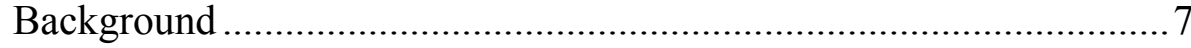

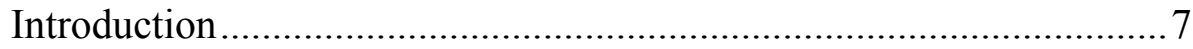

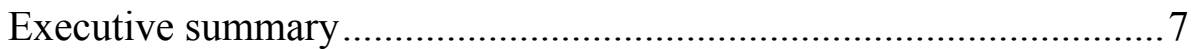

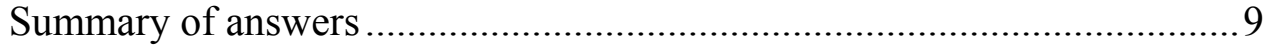

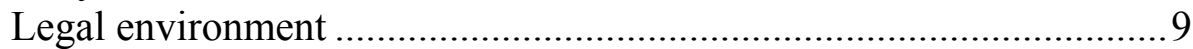

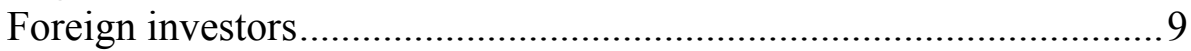

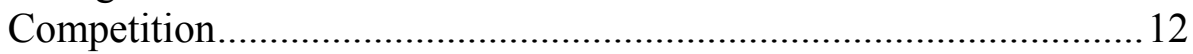

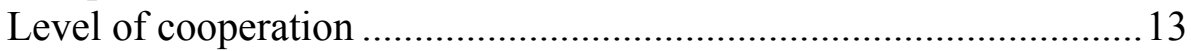

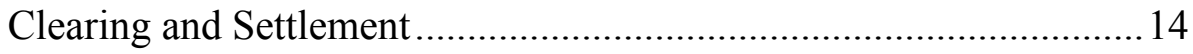

Basic data on Nordic and Baltic Stock Exchanges ............................ 16

Appendix A - Answers from the Nordic and Baltic Stock Exchanges .....21

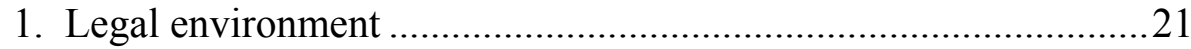

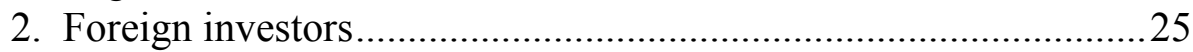

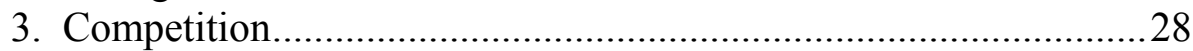

4. Level of cooperation with other exchanges ....................................... 34

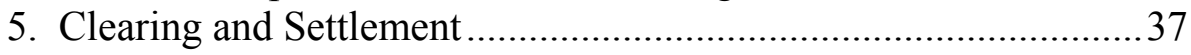

Contact persons for further information ............................................. 43

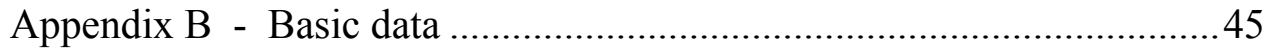

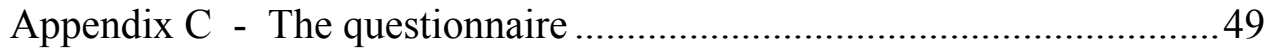




\section{Efficiency in Nordic and Baltic Financial Markets}

\section{Background}

As a follow-up to Dr. Benn Steil's report to the Nordic Council of Ministers in June 1999, a questionnaire prepared by the Nordic Working Group for Securities Market Issues was sent to all Stock Exchanges in the Nordic and Baltic countries. Even if the questionnaire was principally targeted to Nordic market, it was agreed that the option to respond to the questionnaire would also be provided to the Baltic Stock Exchanges. All Stock Exchanges covered by the questionnaire responded to it.

Since 1999 other reports by the Nordic Working Group for Securities Market Issues have shed light on different aspects of the situation, such as "Registrering af værdipapirere i de nordiske lande" in September 2001 and "Clearing og oppgjör i Norden Særlig om forholdet til Giovannini rapporten av november 2001", which focused on 15 different obstacles to effective cross-border clearing. The purpose of this questionnaire was to create a comparison between the Stock Exchanges in the Nordic and Baltic countries and to reveal, in the views of the Stock Exchanges themselves, whether there were any inhibitions to market efficiency that needed to be attended to.

\section{Introduction}

The questionnaire included questions about legal environment, foreign investment, competition and cooperation with other Exchanges and general questions about individual markets. The focus was primarily on the Stock Market and to get the view of the Stock Exchange operators.

In an executive summary highlights from the answers of the Stock Exchanges to the questionnaire are pointed out and areas that appear to need attention are summarized. Following that is a summary of the answers from the Stock Exchanges. Each chapter begins with a description of the questions asked and is followed by a summary of issues pointed out by the Stock Exchanges.

In Appendix A, the complete answers from the Stock Exchanges can be found unchanged and ordered by questions and countries. In Appendix B there are numerical information or basic data on the Stock Exchanges including number of companies listed, equity turnover, number of trades and other information. In Appendix $C$ is the original questionnaire as it was sent to the Stock Exchanges.

\section{Executive summary}

The main views of the Stock Exchange operators are the following:

Clearing and Settlement is with no doubt the single most important issue to be addressed in the minds of the Stock Exchange operators. A separate CSD in each country 
and the lack of efficient cross-border Clearing and Settlement is by all considered to be a major obstacle to efficiency in the Nordic and Baltic Stock market. A central counterparty function, which is today a de facto market standard, is also missing. It is however stressed in the answers that the relevant practitioners should solve these issues.

Cooperation will increase in the following years. The joint trading system SAXESS and the NOREX alliance, plus the OMHEX merger are expected to be followed by further cooperation and mergers. After the horizontal integration that is now almost finalized closer cooperation in clearing and settlement, both in the Nordic-Baltic and European region is to be expected. There are still cost efficiencies that can be obtained by vertical integration supporting cross-border trading in the fields of technical cooperation, sharing of systems and by economies of scale. Mergers are expected to continue and mergers and alliances of local CSD's are seen as potentially improving efficiency and competitiveness towards global/European CSD's. It is also anticipated that consolidation will go further in the rest of the EU.

Too extensive EU regulation is a possible threat to further development and flexibility of the Stock Exchanges. A shift from self-regulation to increased regulation from public authorities can result in too much "red tape" at the cost of efficiency and competitiveness for regulated entities or markets and is considered a threat. The harmonization of legislation in the EU under Financial Services Action Plan (FSAP) will water down some obstacles and create a level playing field for trade matching facilities within the EU. EU regulation must allow for flexible market development and take into consideration the need for separation between different market segments, special needs of issuers, market participants and markets of different sizes.

Taxation is an obstacle to efficient cross-border trading. Different rules about capital gains tax and withholding tax complicate foreign access and there is a lack of legal definitions and taxation rules and symmetries for modern financial concepts and products, like hedge funds, hedge fund related activities, stock lending and borrowing and derivatives.

Legal obligations on the CSD's, both limitations on the degree of integration allowed between Stock Exchanges and CSD's and other statutory roles that the CSD's are required to perform limit the possibility of integration between CSD's and Stock Exchanges.

Transparency rules are working to the benefit of the Stock Exchanges. They should be set at an internationally acceptable level, with as few country specific rules as possible. On the other hand central counterparties and anonymous trading need to be an option. The need for anonymous trading must be addressed when transparency rules are made. Frequency of financial reporting should also be left to individual Stock Exchanges and not put in EU regulation.

Competition is global and for the Stock Exchanges the benefits of cooperation in the Nordic and Baltic countries greatly outweighs threats of Nordic-Baltic competition. For the Nordic and Baltic financial market to succeed in the global competition further cooperation between the Nordic and Baltic Stock Exchanges and especially more cooperation with and between the CSD's and establishment of standard technology between the CSD's is a key to increasing competitiveness towards global/European CSD's. 


\section{Summary of answers}

\section{Legal environment}

The Stock Exchanges were asked if they could identify any laws that unnecessarily limit the efficiency of their markets. The questions focused on taxing laws, laws on foreign investment, laws regarding pension funds or any laws or regulations that did affect the market negatively. The following laws or areas of business were identified:

Taxing laws: Capital gains tax and withholding tax.

Hedge funds: No legal definitions for hedge funds or rules for taxation of hedge fund related activity.

Derivatives: Lack of symmetry of taxing between equities and derivatives based on those equities.

Borrowing of stock: Lending stock is seen as selling and taxed as such while return is seen as buying. Laws are not up to date regarding repos.

Main and secondary lists: Different tax regimes for stock on main and secondary lists.

Dividends: When dividends are paid in shares it is not possible to withhold tax as no cash is distributed to the investors.

Laws restricting foreign investment: A maximum percentage of foreign investment in certain sectors. Still practiced in Norway and Iceland.

Pension funds: Limitations on the ratio of equities in pension funds.

CSD's: Legal obligations on the CSD's, both limitations on the degree of integration allowed between Stock Exchanges and CSD's and other statutory roles that the CSD's are required to perform.

\section{Foreign investors}

Foreign investors have different ways of accessing Nordic and Baltic markets. A few questions were asked to quantify foreign access to Nordic and Baltic Stock Exchanges and stock markets. The following graphs summarize the results. 


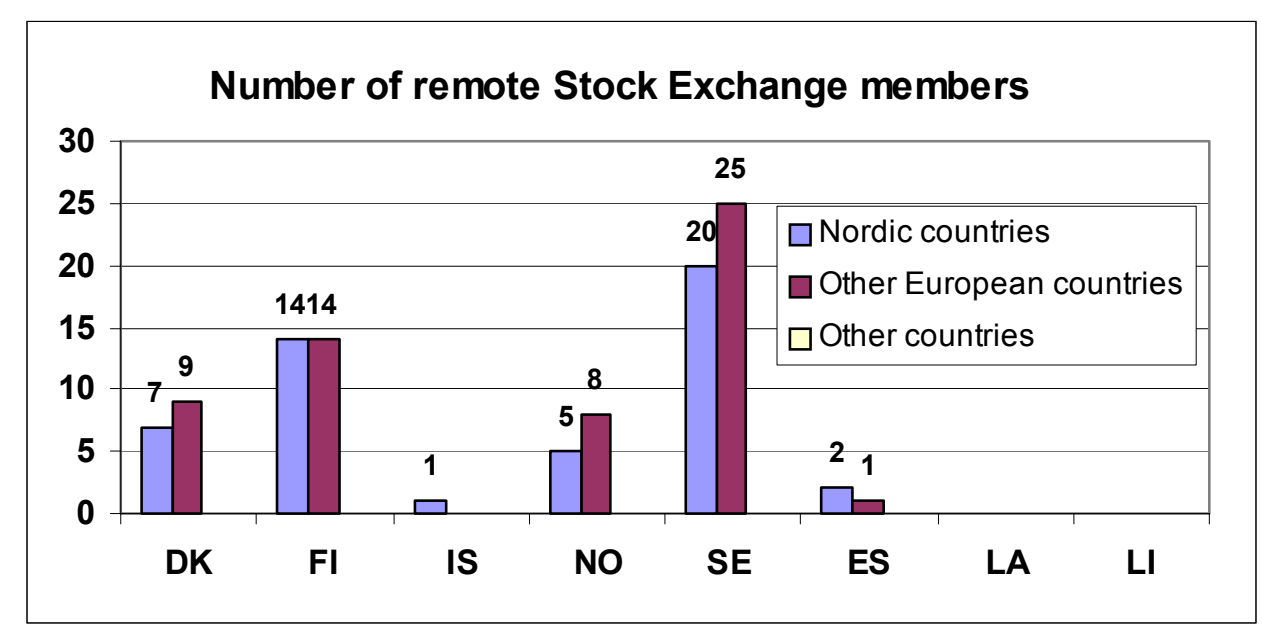

Denmark, Sweden, Norway and Finland have between 13 and 45 remote members in their Stock Exchanges so this way of foreign access to Nordic Exchanges is quite common. The remote members are both from other Nordic countries and other European countries, but still there are no remote members to the Stock Exchanges from outside Europe. Several non-European banks and investment firms have subsidiaries in London and are remote members from there.

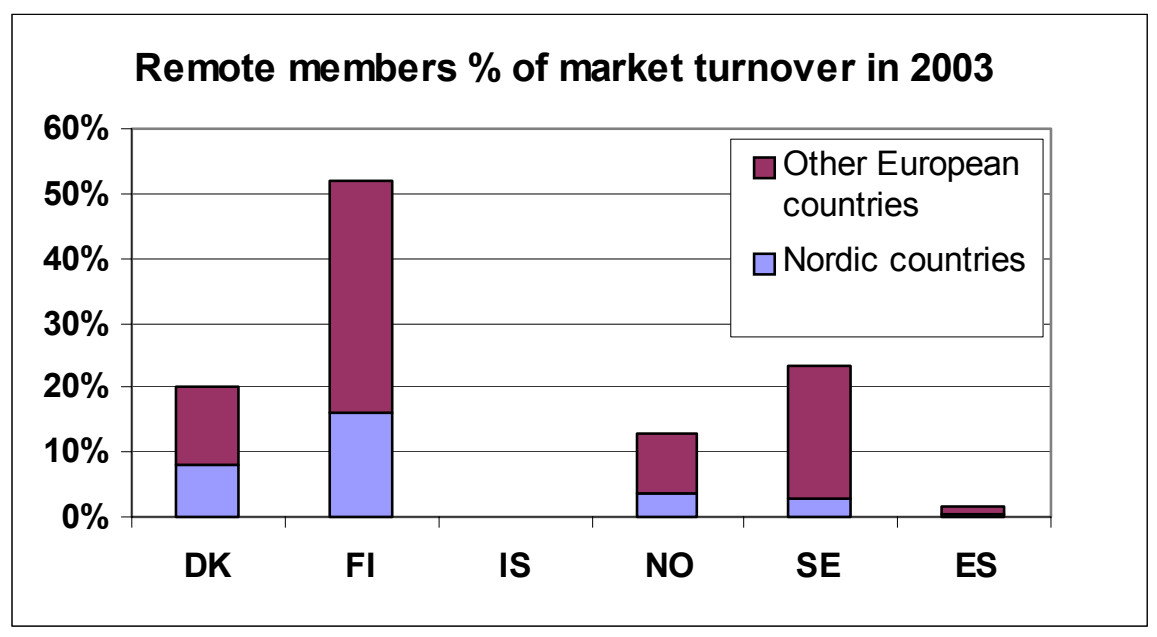

The remote members' market share varies from zero in Iceland to 52\% in Finland. In Norway, Sweden and Denmark the turnover share of remote members in 2003 was between $13 \%$ and $23 \%$ of total turnover. 


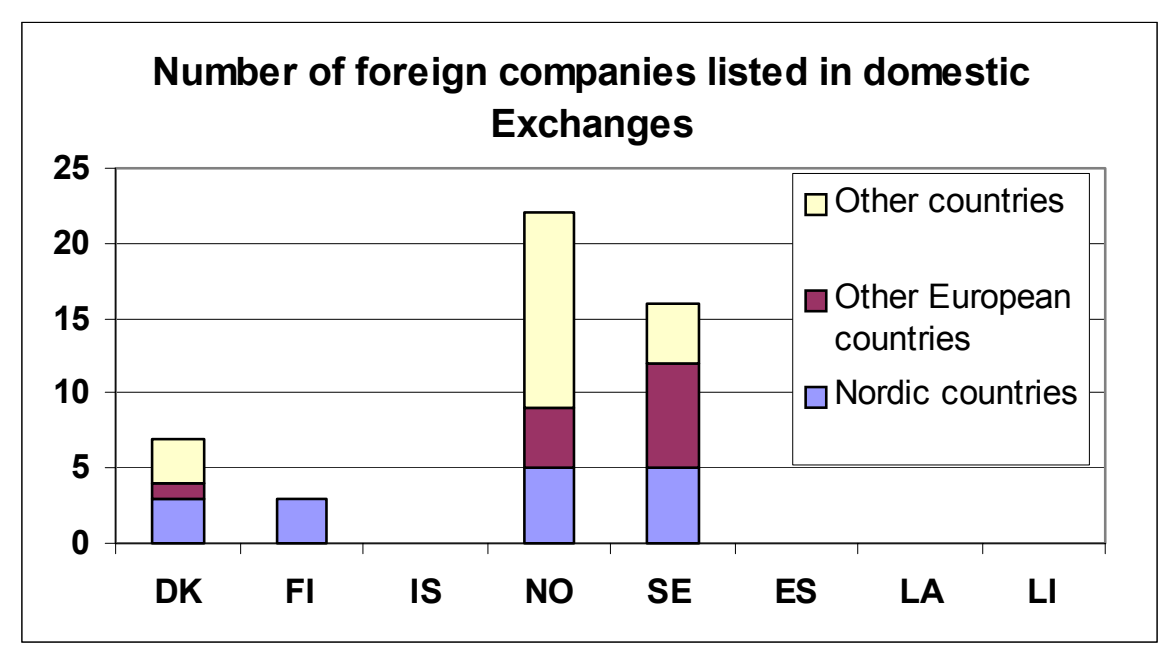

Norway, Sweden, Denmark and Finland have foreign companies listed in their Stock Exchanges. Norway has most or 22 foreign companies listed while Finland has 3 foreign companies listed. From other Nordic countries there are 3 to 5 foreign companies listed while from other European countries there are between 1 and 7 foreign companies listed. Norway has most companies listed from countries outside Europe (13) while Sweden has 4 and Denmark 3.

Only Iceland and Denmark have domestic companies that only have a foreign listing Iceland one outside Europe and Denmark 1 in Europe and 1 outside Europe.

Changes since 1999:

The Stock Exchanges were also asked what they considered the most significant changes in the accessibility of foreign investors, members and companies to their market since 1999. According to them the biggest change has been the NOREX alliance and the joint trading system SAXESS that the Stockholmsbörsen and the Copenhagen Stock Exchange started using first. Iceland and Norway joined the alliance later and now also Finland has joined and will thus start to use SAXESS on September 2004. The same applies to Estonia and Latvia and presumably in the future also to Lithuania. Centralization of the Finnish depository system and launch of their new clearing and settlement system (HEX-Clear) has facilitated access of foreign members to the Finnish CSD and settlement facilities.

In Lithuania the laws on foreign investment have been relaxed since 1999 to allow for investment in all spheres of economic and commercial activity with the exception of the state security and defense sector. Estonia has relieved the terms for cross-border listing and securities trading and in May 2004 the Investment Services Directive will be enforced. The Riga Stock Exchange, since end-March has made trading possible in EUR and USD.

Obstacles still remaining.

All of the Nordic Stock Exchanges consider the lack of efficient cross-border clearing and settlement to be an obstacle for foreign investors. Each country has its own separate Securities Depository so there is strong demand for some improvement in this area. The Baltic countries do not specify any obstacles, but Latvia mentions the small size of its market as a cost barrier for remote members. 


\section{Competition}

The questionnaire included a few questions about competition and what the Stock Exchanges consider to be their competitive market. Currencies used in each Stock Exchange, transparency rules and how those might affect the competitive status of the Exchanges were also in question. The Stock Exchanges were also asked for views about possible threats or opportunities in the changes that are and will be happening in the Nordic-Baltic and/or European stock markets or legislation within the next few years.

The Stock Exchanges see the global market as their competitive area. Some also focus on competition for domestic capital within their local market. Threats can also be seen as opportunities and for some Exchanges the advantages of cooperation between the Nordic markets outweighs the threat of competition. In the global market the competition is about attracting investors and Oslo Børs considers US and UK to be most important in that respect. They also say that the competition for attracting brokers/members is mainly European due to US-law. Competition is also focused on investors that have special interests in the Nordic and Baltic region.

The global focus of the Stock Exchanges and the merging of Nordic and Baltic markets with the global environment including new technologies that are forthcoming will challenge the regulatory framework to allow for cross-border trading and settlement. It is important to define rules that are not country specific nor based on national laws of the host. Flexibility should at least be made possible for the more professional parties even if national rules are applied for "household" investors.

All Stock Exchanges consider their rules for transparency to positively affect their competitive status. Some suggest that transparency rules be set at an internationally acceptable level, that is "best practice" and that there is no room for country specific rules. Anything less than that will affect the competitive status negatively. The idea to tone down country specific features is supported. On the other hand it is mentioned that the European tendency to implement central counterparties, which makes anonymous trading possible, does not allow for full transparency. So the need for anonymous trading must be addressed when transparency rules are made. Some segments of particular markets may find quarterly reporting inappropriate so it is urged that the frequency of financial reporting is not determined in law, especially not EU law and it would be better to leave the frequency up to the individual Stock Exchanges to decide on that.

Some Stock Exchanges only deal in their domestic currency and it is currently not considered having a negative impact on their competitive status. Only Copenhagen Stock Exchange allows for trading in any currency and they consider it to be potentially important in a competitive environment to be able to trade foreign securities in their home currency. Oslo Børs estimates it to be important in future years, to have the availability for trading in foreign currencies. In Tallinn Stock Exchange the trading currency is EUR and in Finland where EUR is the domestic currency the euro is considered to contribute positively to competitive status. Stockholmsbörsen allows for trading in EUR, but they do not see it as having a major effect on their competitive status. In Iceland it is possible to trade in DKK and they are working towards being able to trade in EUR and USD.

The Nordic cooperation, especially the NOREX Alliance with further integration of the Nordic and Baltic region is seen as a positive development creating opportunities and facilitating cost efficiencies that maintain the competitive advantage for the Exchanges. 
There is fear that EU regulation will be too extensive both on Level 1 and Level 2. A shift from self-regulation to increased regulation from public authorities will result in too much "red tape" at the cost of efficiency and competitiveness for regulated entities or markets and is considered to be a threat. Still the harmonization of legislation in the EU under FSAP is seen as beneficial in the sense that it waters down some obstacles. That will create a level playing field for trade matching facilities within the EU. There is also fear that EU regulation will not allow for flexible market development or take into consideration the need for separation between different market segments, special needs of issuers, market participants and markets of different sizes. Harmonization of best practices within given targets will therefore not necessarily be the case.

The lack of a common Nordic clearing and settlement facility and a central counterparty is considered to diminish the possibility for cost efficiencies. On the other hand the establishment of such a facility would create such benefits. The maintenance of five different currencies is in a narrow perspective to the advantage of the Nordic Exchanges, but in the long run an impediment to the creation of an efficient Clearing $\&$ Settlement solution.

The merger of OM and HEX is seen as a beginning of a very important and welcome increase of cooperation between Nordic and Baltic countries and such cooperation is expected to increase in future years.

\section{Level of cooperation}

The Stock Exchanges were asked about the level of cooperation with other Stock Exchanges. Ownership of the Stock Exchange including other operations of major owners was also asked. The Stock Exchanges were also asked if they expected increased cooperation or mergers, including vertical integration, within the European stock market in the next few years.

The Stock Exchanges in Iceland, Norway, Denmark and Sweden currently use a joint trading system, SAXESS. Stock Exchanges in Finland and Estonia also use a joint trading system and by September 2004 Stock Exchanges in Finland, Estonia and Latvia will join with the Nordic countries and implement the SAXESS trading system, used by the NOREX markets.

Ownership of all Stock Exchanges is at least partly domestic. In Iceland, Denmark and Lithuania the ownership is purely domestic. The new company OMHEX created by the joining of the Swedish OM and the Finnish HEX has full ownership of the Swedish and Finnish Stock Exchanges plus 93\% in the Latvian and 62\% of the Estonian Stock Exchanges, leaving 7\% domestic ownership in Latvia and 38\% in Estonia. In Norway the ownership of the Oslo Børs is a mixed domestic, Nordic and American ownership.

The OMHEX AB, which operates the Stockholm, Helsinki, Tallinn and Riga Stock Exchanges, also operates the CSD's in Finland, Latvia and Estonia.

There is IT related cooperation amongst the NOREX Exchanges including surveillance systems, indices, web and data feed distribution system. Stockholmsbörsen has a trading and clearing link with regard to derivatives with the Norwegian and Danish markets and outside the Nordic region in Europe a trading and clearing link with regard to derivatives with EDX and LCH in the UK. HEX has cooperation with Eurex with respect to Finnish derivatives traded on Eurex. Tallinn and Riga Stock Exchanges have ongo- 
ing further integration projects into joint Baltic markets. Lithuanian National Stock Exchange also says it has other cooperation in the Nordic and European region.

Further cooperation and consolidation is expected within the next few years, in trading as well as clearing and settlement, both in the Nordic and European region. On the trading level, horizontal integration is close to be finalized, either by way of mergers or cooperation. It is expected that the Nordic market will within a few years have in place a central counterparty, like most EU-markets. There are still cost efficiencies that can be obtained by vertical integration by supporting cross-border trading, in the fields of technical cooperation, sharing of systems and by economies of scale. Mergers are expected to continue and mergers and alliances of local CSD's are seen as potentially improving efficiency and competitiveness towards global/European CSD's. Further consolidation is also anticipated in the rest of EU. In Lithuania the National Stock Exchange is undergoing privatization and part of state-owned holdings of the CSD in Lithuania will be sold as a step into integrating the domestic securities market in the single European market. Potential buyers of NSEL and CSDL are OMHEX and the Warsaw Stock Exchange.

\section{Clearing and Settlement}

The Stock Exchanges were asked about their Clearing \& Settlement systems and how they estimate them to affect their competitive status. The clearing and settlement day rule was asked about and its effect on competition. They were also asked about the most likely or "in practice" way for foreign investors to trade in their Stock Exchange.

All Nordic and Baltic countries have their own separate Clearing and Settlement system. And still there has not been established a central counterparty to simplify crossborder settlement. The lack of efficient cross-border Clearing \& Settlement is considered to be the single biggest competitive challenge in the Nordic-Baltic region. CCP function is a de facto market standard today because it removes the counterparty risk between two parties in trading and allows for completely anonymous trading. CCP also creates the possibility to net all trades in a given security. So the lack of these functions is considered to reduce Nordic and Baltic competitiveness in the global context.

Cross-border settlement is the most expensive part related to trading across borders. In spite of the fact that trading across borders is now easy and simple, there is still a need for a CCP offering one matching cycle (linking exchange and CSD) to reduce costs. There are some FOP-links (Free Of Payment) between the 5 different CSD's in the Nordic region, but the lack of operational DVP-links (Delivery Versus Payment) or standard technology between the CSD's is a big problem. It is however stressed that the relevant practitioners should solve these issues.

In Lithuania the CSD of Lithuania and Bank of Lithuania carry out Clearing \& Settlement functions and the current status is considered to affect the competitive status favorably. In Estonia the Stock Exchange is the full owner of the CSD, which they consider to enable better cooperation and solutions for the market participants. Clearing \& Settlement takes place within the same group in Finland, Estonia and Latvia. In the overall market perspective it strengthens the market competitiveness by providing possibilities for integrated trading solutions and by enabling direct market-wide development and management of the full value chain. The combining of all infrastructure services of Finnish, Estonian and Latvian securities market chain under one roof is consid- 
ered by the Stock Exchanges to offer more effective services to customers, both in the home country and abroad. This vertical group structure has provided more flexibility and faster reaction to changes and has facilitated - not hindered - cross-border investment.

$\mathbf{T}+\mathbf{3}$ or settlement three working days after trading is the standard rule in the Nordic and Baltic region. Only Iceland has $\mathrm{T}+1$ as their standard. There are also some deviations from the standard rule in the Baltic countries for negotiated deals or government securities. The Iceland Stock Exchange sees their different standard to have a negative effect on its competitive status for two reasons. Firstly, because it is different from international standards of $\mathrm{T}+2$ or $\mathrm{T}+3$ and secondly, because currency settlement takes place at $\mathrm{T}+2$. So $\mathrm{T}+1$ is likely to limit the participation of foreign investors in the Icelandic market.

Other Nordic and Baltic countries consider their settlement rules either to have no major impact or a favorable impact on their competitive status as it complies with international standards. The United States are moving towards real-time settlement, with $\mathrm{T}+1$ as a target, but still it is considered that the move toward straight through processing (STP) with a low proportion of manually handled settlement is of more importance.

Foreign investors have access to markets in the Nordic and Baltic countries through local members of the Stock Exchanges and in some cases through local financial institutions that are not members themselves but go through other local members. In countries like Norway, Sweden, Denmark and Finland there is a growing number of remote Stock Exchange members that have straight access to the trading platform. The most complicated aspect of foreign access to trading is clearing and settlement. If a link agreement has been made between CSD's, a transfer can be made directly between such CSD's without a need to be converted through the books of a custodian bank. Without such a link a custodian that is a member of the local CSD is needed. The general rule is: the shorter the "distance" or number of parties involved in the process, the cheaper the trading is.

Finland has established CSD links with Sweden, Germany, France and the Netherlands and the interest in direct remote access to the clearing and settlement system is growing. For other Nordic and Baltic countries a remote membership in a Stock Exchange and a settlement through a settlement agent that is a member of the CSD in the Stock Exchange's home country is still the best option. This would then be dependent on a prior agreement with a custodian that the holdings of the foreign investor would be registered to. In Norway a US or UK investor would usually place an order through a UK member that would sometimes find another UK member as a counterparty. In Iceland a direct participation of foreign members through a remote link is minimal and neither Latvia nor Lithuania have remote members, but Estonia has three already. So for most Nordic and Baltic countries access for foreign investors is still considerably more costly than for local participants. 


\section{Basic data on Nordic and Baltic Stock Exchanges}

The four Stock Exchanges in Denmark, Norway, Sweden and Finland are comparable in size with 145 to 282 companies listed at end of year 2003. The Iceland Stock Exchange is comparable to the Baltic Stock Exchanges that have between 14 and 56 companies listed.

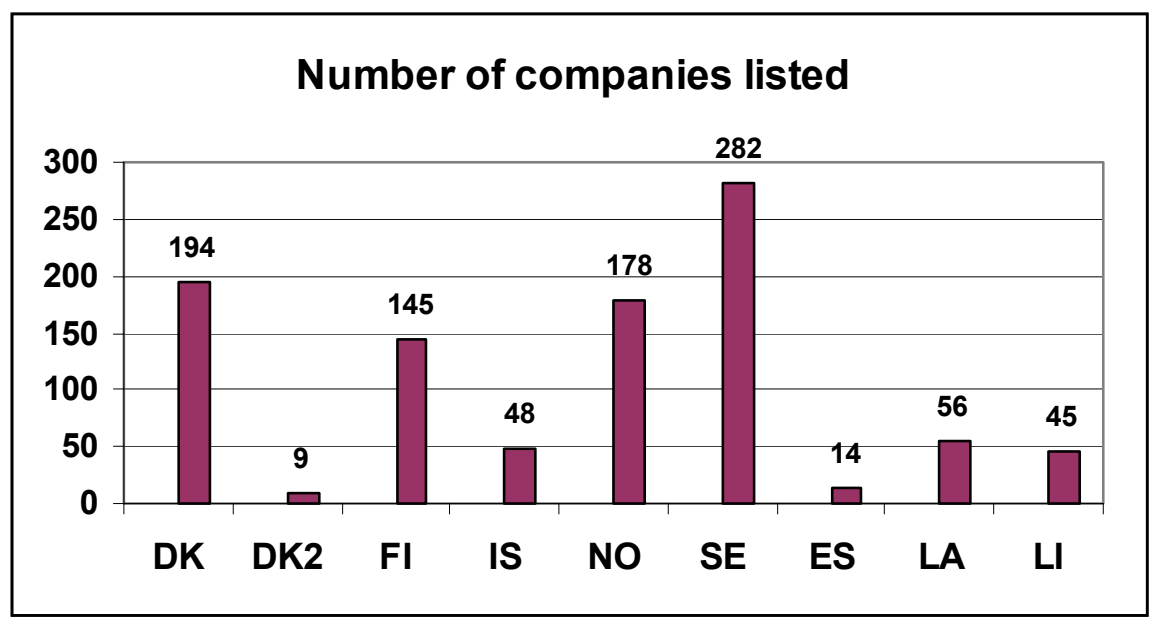

It is obvious that even if the Stock Exchanges say that transparency rules have a beneficial effect on their competitive status that for some reason there are more companies delisted from the Stock Exchanges than are becoming listed. In the Nordic and Baltic countries 2 to 6 new companies have been listed in each Stock Exchange but up to 30 companies have delisted at the same time.

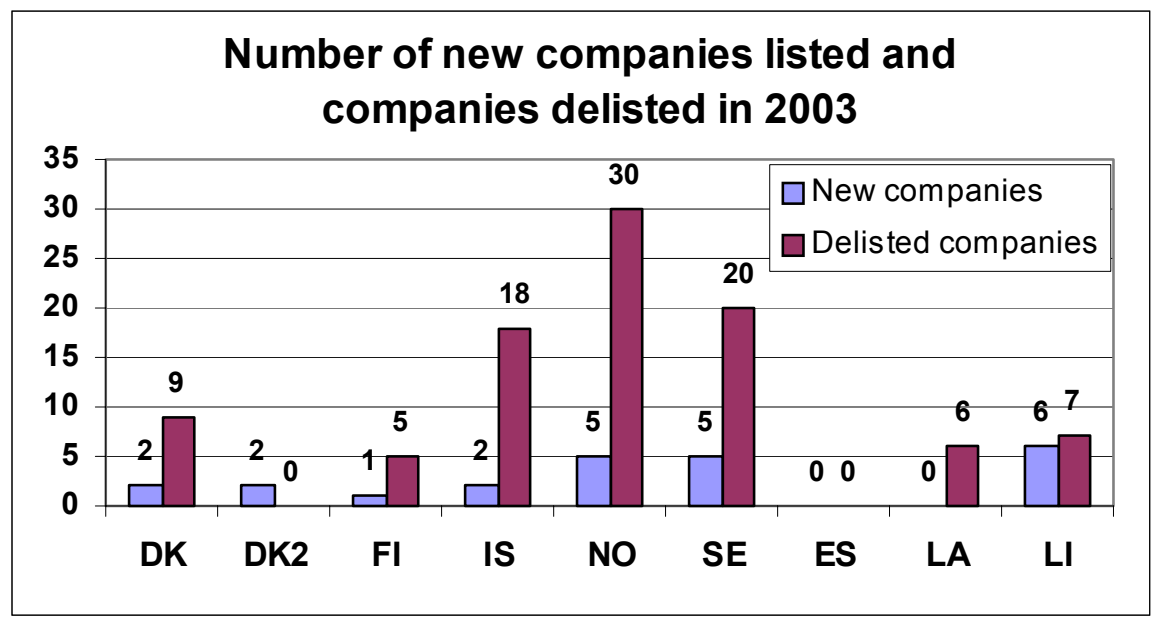

The turnover has decreased in Finland, Sweden, Latvia and Lithuania. In Denmark, Iceland, Norway and Estonia the turnover has increased between years 2002 and 2003. 

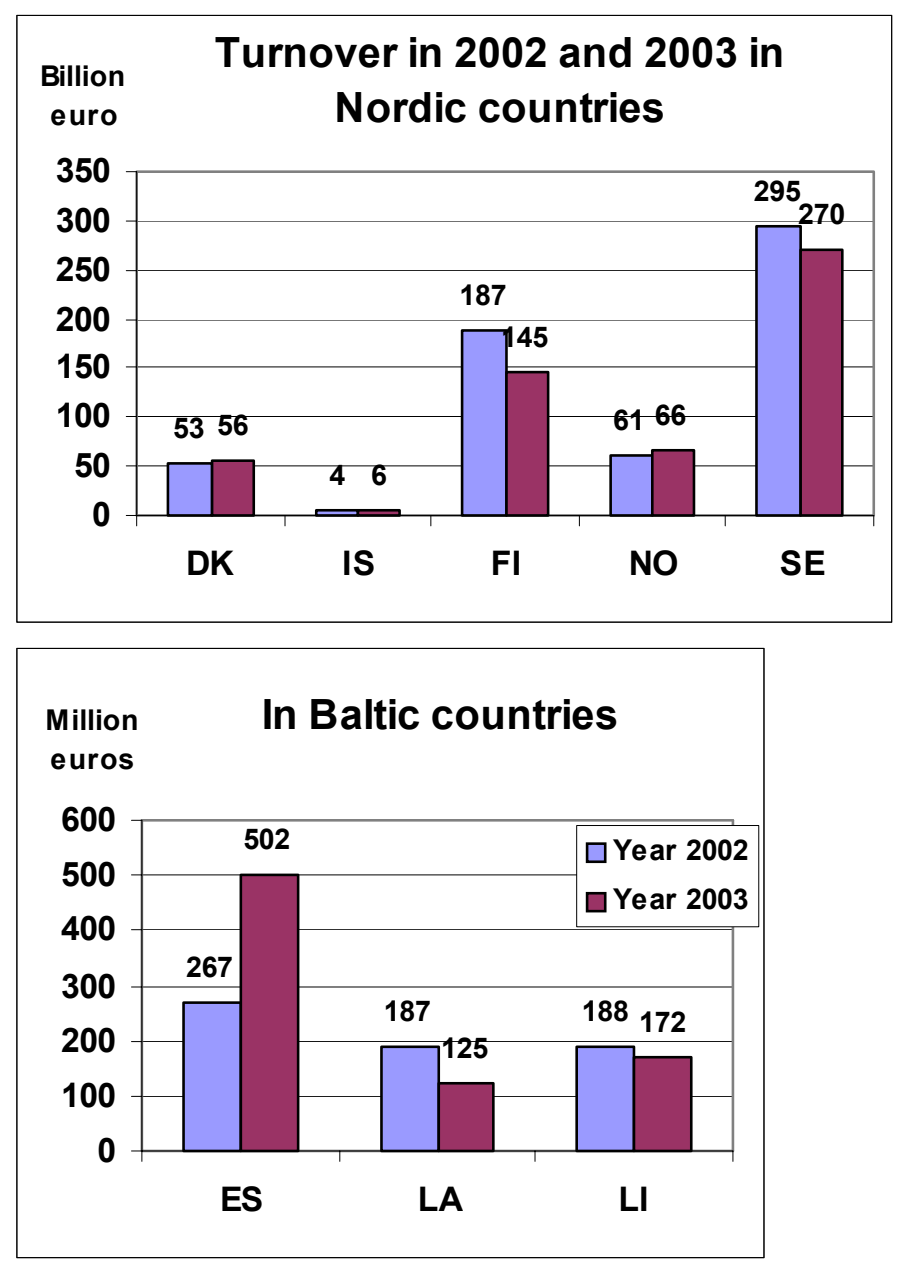

The number of trading days in the year 2003 was similar in all countries, fewest in Iceland (246) and most in Lithuania (254).

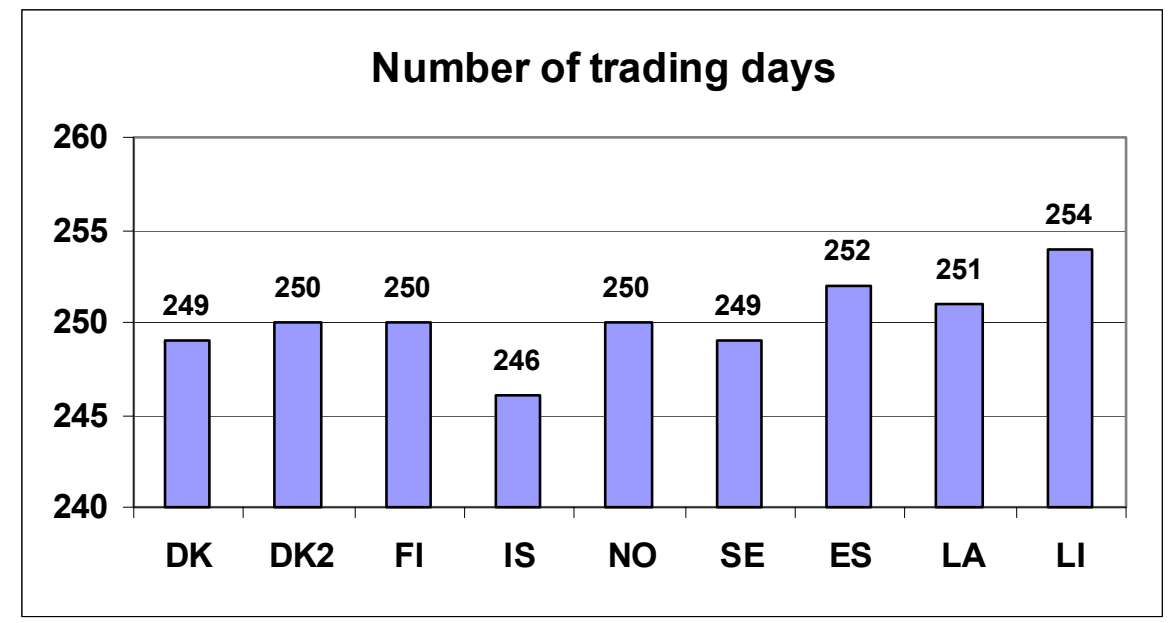

Here the turnover in 2003 is divided among the top 5, top 10 and top 15 companies listed in the Stock Exchanges. In most of them the top 5 companies have close to $50 \%$ or more of the total turnover. 

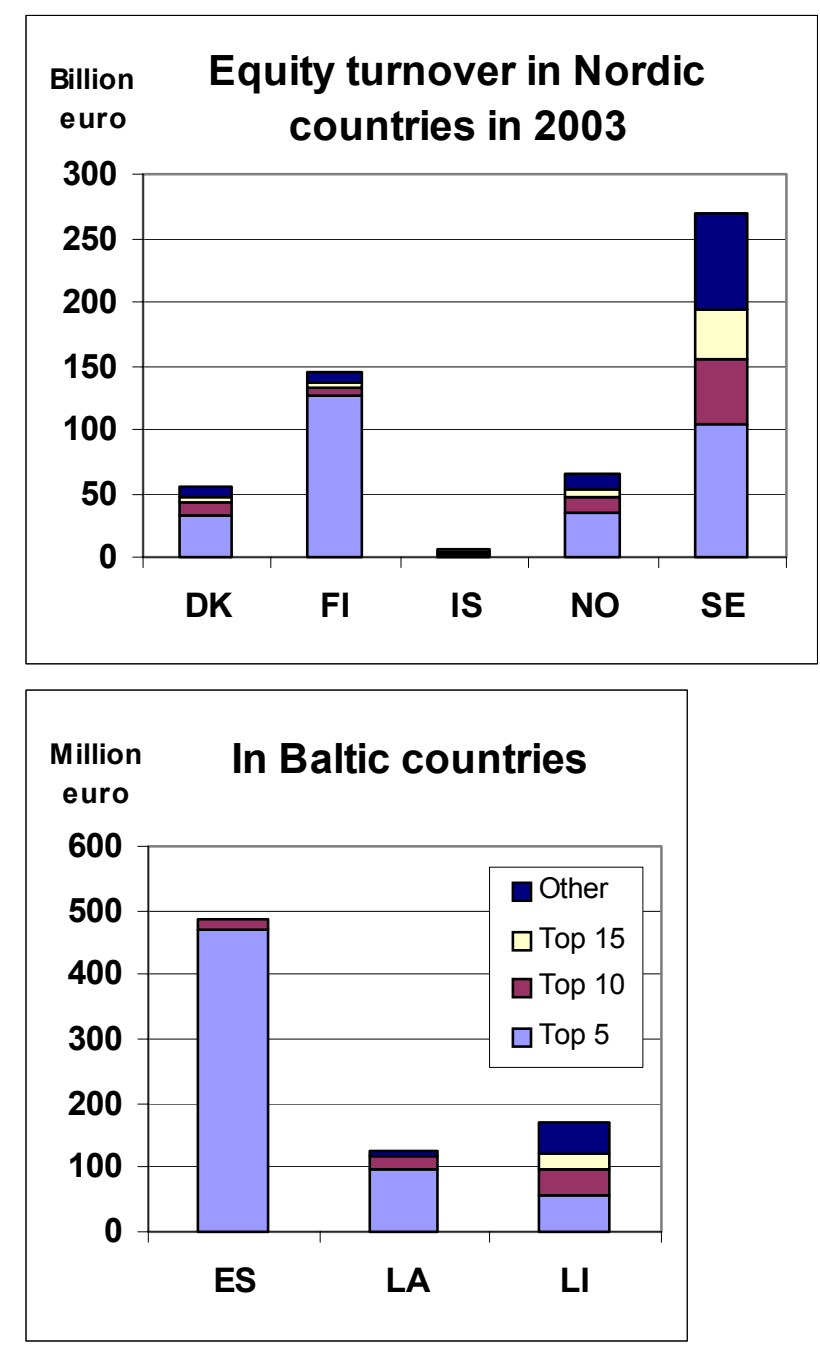

This can be seen more clearly in the next graph that shows equity turnover as percentage between top 5, top 10, top 15 and other companies.

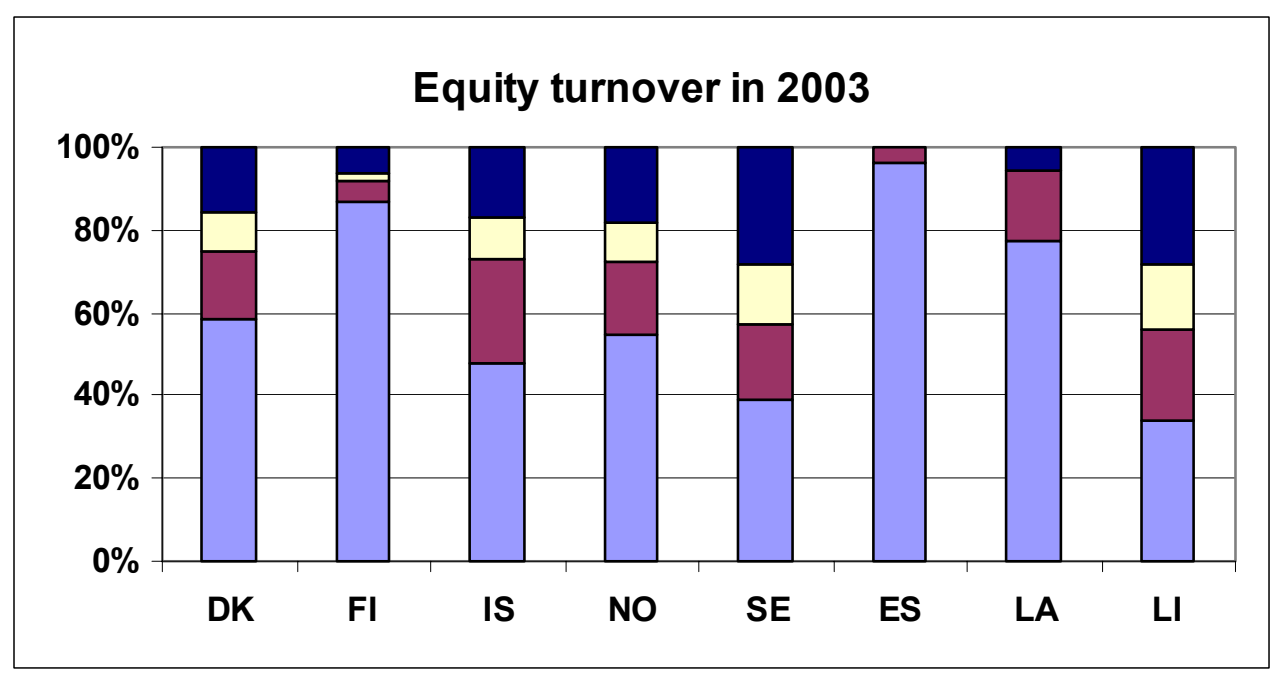

The graphs below show the number of trades in the Nordic and Baltic countries. 

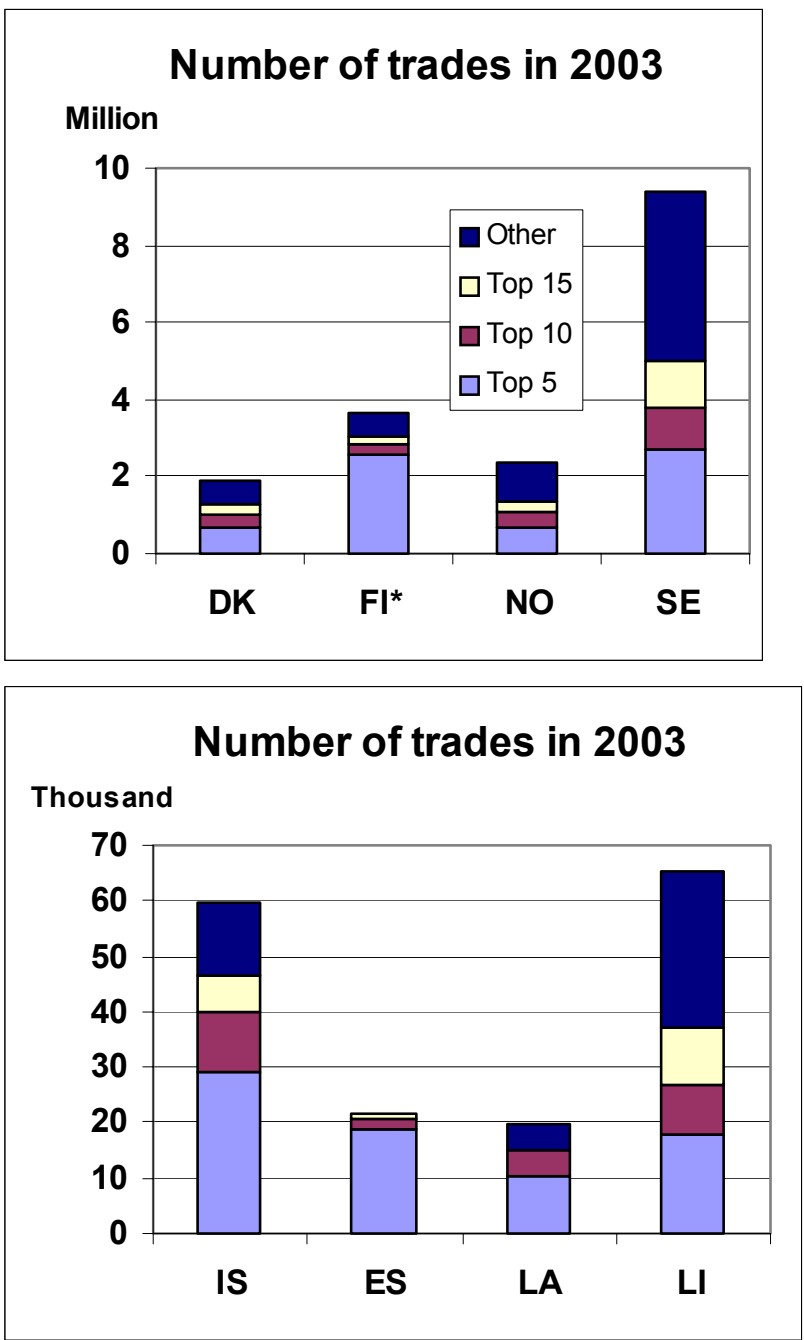

Turnover rate in 2003 is close to $100 \%$ in the Nordic countries. It is considerably less, i.e. between 4 and $16 \%$ in the Baltic countries.

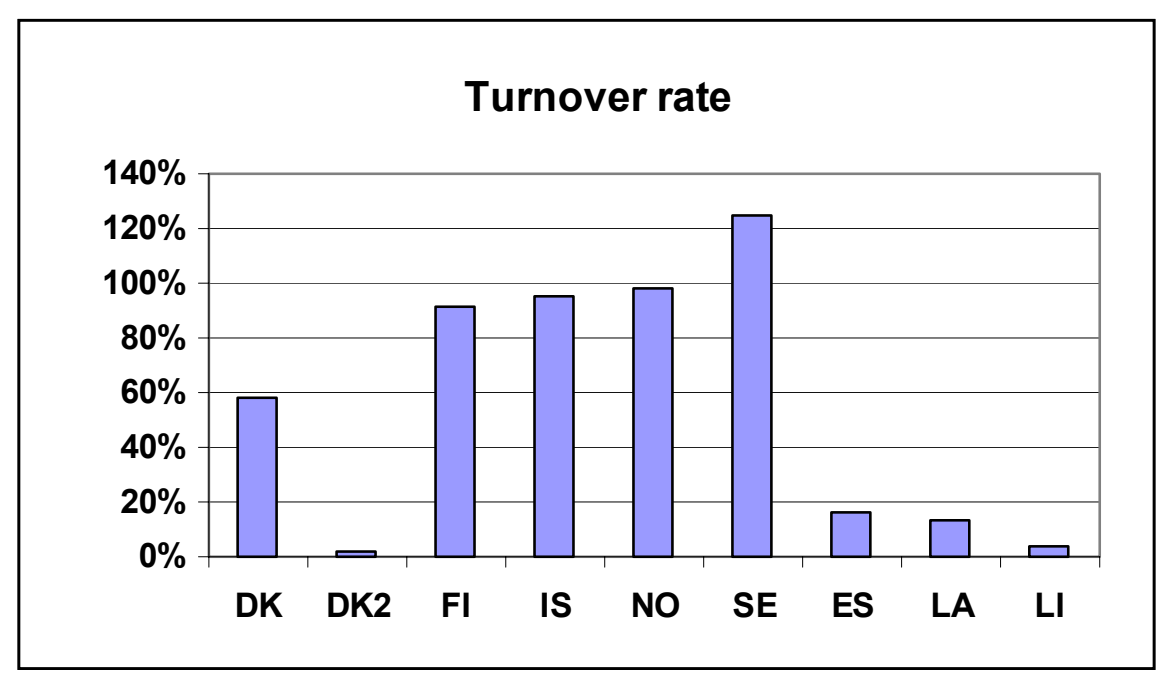




\section{Appendix A - Answers from the Nordic and Baltic Stock Exchanges}

The following symbols are used in tables:

$\begin{array}{lll}\text { DK } & \text { Denmark, Copenhagen Stock Exchange } \\ \text { DK2 } & =\text { Dansk Autoriseret Markedsplads } \\ \text { FI } & =\text { Finland, HEX Integrated Markets } \\ \text { IS } & =\text { Iceland, ICEX } \\ \text { NO } & =\text { Norway, Oslo Børs } \\ \text { SE } & =\text { Sweden, Stockholmsbörsen } \\ \text { ES } & \text { Estonia, Tallinn Stock Exchange } \\ \text { LA } & =\text { Latvia, Riga Stock Exchange } \\ \text { LI } & =\text { Lithuania, National Stock Exchange of Lithuania } \\ \text { - } & =\text { NA, Not applicable }\end{array}$

\section{Legal environment}

The purpose of the following questions was to identify, whether there were any laws or legal rules that unnecessarily hinder the efficiency of markets related to increased liquidity, increased depth of the market, decreased spreads or costs etc.

a) Are there any taxing laws that limit the efficiency of your market?

\begin{tabular}{|l|l|l|l|l|l|l|l|l|}
\hline DK & DK2 & FI & IS & NO & SE & ES & LA & LI \\
\hline Yes & No & Yes & Yes & Yes & Yes & No & No & Yes \\
\hline
\end{tabular}

Denmark: (General: It should be noted, that the legal environment in the Nordic and Baltic region is primarily and predominantly affected by EU legislation, to which all Nordic countries are subject to, either by membership of the EU or by having committed themselves to implement EU legislation.

Therefore - in general - efforts should be made to co-ordinate the views and needs of the Nordic and Baltic markets in such a way as to achieve the biggest impact on EU legislation.

In this respect, this initiative of the Nordic Council may be seen as a valuable first step in identifying areas of common interest.)

The taxation of capital gains on equity investment in Denmark is very complicated and difficult for investors to understand. This is undoubtedly one of the reasons why the Danish equity culture is still lagging behind other Nordic and European countries. The taxation of derivatives does not allow for compensation between the derivatives and the 
underlying instruments. Hence derivatives cannot be used for hedging purposes. Although this questionnaire only deals with equity, this aspect is important, since a well functioning and liquid derivatives market is very important to the cash equity market.

There is no legal definition of a hedge fund, and therefore no specific taxation rules for hedge funds either. Consequently taxation of any "hedge fund related" activity would be according to the individual instruments invested in.

Concerning stock borrowing and lending, the main problem on the lending side is that lending in some cases may be regarded as a sale and thereby due to taxation. On the borrowing side the main problem is that taxation is asymmetric, e.g. income on shorting transactions is due to taxation without deduction for lending costs.

Finland: The Finnish tax laws (e.g. Act on business income tax and Act on asset transfer tax) have in several cases hampered the development of securities market practices and thus the efficiency of the market. For example, the tax laws have hampered and in some cases even blocked the development of securities lending facilities as well as the use of efficient collateral arrangements. This is currently the case e.g. with regard to the collateral arrangements provided in the Collateral Directive.

The proposed new Finnish corporate and capital income taxation will likely lead to less incentives for direct investing in securities which will, in turn, reduce liquidity.

With regard to lacking neutrality on taxation (e.g. wealth tax) of different investment products, we refer to a recent report of a Ministry of Finance working group.

Iceland: No further comments provided.

Norway: Withholding taxes are still a big problem, which is constantly addressed by foreign investors. For mutual funds there is no symmetry between taxation of equities and derivatives. Hence derivatives cannot effectively be used for hedging purposes. Although this questionnaire only deals with equity, this aspect is important, since a well functioning and liquid derivatives market is very important to the cash equity market. Although these laws do not hinder foreign investment, they reduce the attractivity of our market.

Sweden: i) The different tax regimes with regard to the A-list and the O-list. ii) The tax on capital when units in funds are divested and the proceeds are used to reinvest in other such funds. iii) The dividend tax for foreign investors in case of dividend in the form of shares (in those situations, the Swedish CSD - VPC - is required by law to withhold the tax on behalf of the investor, even though no cash is distributed to the investor).

Estonia: No further comments provided.

Latvia: No further comments provided.

Lithuania: As of 1 January 2003, a capital gains tax is imposed on gain from shortterm investments received by individuals. The flat tax rate is $15 \%$. Investments are considered to be short-term when securities are sold earlier than 366 days following their acquisition. The introduction of the capital gains tax may be considered as a certain impediment to a more active trading of retail investors on the market. 
b) Are there any laws hindering foreign investment in your market?

\begin{tabular}{|l|l|l|l|l|l|l|l|l|}
\hline DK & DK2 & FI & IS & NO & SE & ES & LA & LI \\
\hline No & No & No & Yes & NO & No & No & No & No \\
\hline
\end{tabular}

\section{Denmark: No further comments provided.}

Finland: No further comments provided.

Iceland: General: It should be noted, that the legal environment in the Nordic and Baltic region is primarily and predominantly affected by EU legislation, to which all Nordic countries are subject to, either by direct membership to the EU or by membership to the European Economic Area (EEA).

Therefore - in general - efforts should be made to co-ordinate the views and needs of the Nordic and Baltic markets in such a way as to achieve the biggest impact on EU legislation. In this respect, this initiative of the Nordic Council may be seen as a valuable first step in identifying areas of common interest.

Legal environment: Foreigners are allowed to invest in the stock market as well as in other financial instruments in Iceland, however, they can only own up to $25 \%$ in legal persons, which conduct fishing operations within the Icelandic fisheries jurisdiction according to the Act on Investment by Non-residents in Business Enterprises No. 34/1991. The restriction applies to listed fishery companies at the Iceland Stock Exchange. Foreign citizens or legal persons outside of the EEA and the EFTA states are not permitted to own enterprises, which produce or distribute energy. At the moment the latter restriction does not affect the stock market since no such companies are listed but this could of course change when such companies will be privatized. It might though delay liberalization and privatization in that sector. Foreign citizens and legal persons outside of EEA and EFTA may only own up to $49 \%$ in domestic airline companies.

Norway: Withholding taxes.

Sweden: No further comments provided.

Estonia: No further comments provided.

Latvia: No further comments provided.

Lithuania: No further comments provided.

c) Are there any laws regarding pension funds that limit the efficiency of your market?

\begin{tabular}{|l|l|l|l|l|l|l|l|l|}
\hline DK & DK2 & FI & IS & NO & SE & ES & LA & LI \\
\hline Yes & No & No & Yes & Yes & No & No & No & No \\
\hline
\end{tabular}

Denmark: The rules governing the investments for pension funds are still limiting the amount of funds, which can be invested in equity. In the private sector, it is very expensive to move your account from one pension fund to another, which inhibits the competition between these funds

Finland: No further comments provided. 
Iceland: The rules governing investments for pension funds are limited to a certain ratio of the complete portfolio in equities, some types of bonds and some other types of financial instruments.

Norway: The rules governing the investments for pension funds are still limiting the amount of funds, which can be invested in equity and derivatives.

Sweden: No further comments provided

Estonia: No further comments provided.

Latvia: No further comments provided.

Lithuania: No further comments provided.

d) Are there any other laws or regulations that negatively affect the efficiency of your market?

\begin{tabular}{|l|l|l|l|l|l|l|l|l|}
\hline DK & DK2 & FI & IS & NO & SE & ES & LA & LI \\
\hline No & No & Yes & Yes & Yes & Yes & No & No & No \\
\hline
\end{tabular}

Denmark: No further comments provided.

Finland: No further comments provided.

Iceland: There are legal limits to the degree of integration allowed between the Iceland Stock Exchange and the Icelandic Securities Depository (the ISD). It should also be noted that the main rules of the Act Respecting Publicly Limited Liability Companies No. 2/1995 are from the year 1978. At the time there was no stock market and therefore the Act does not take into account that companies can be listed and what that entails. Therefore the Act needs to be updated. .

Norway: In Norway fund managers cannot offer hedge funds to their clients. This has led to Norwegian fund managers establishing hedge funds in Sweden and other countries.

Sweden: The statutory role for a Swedish CSD with regard to handling tax issues and corporate actions on behalf of a Swedish Registered Company "Avstämningsbolag" has a negative effect by not facilitating sufficient degree of flexibility. In particular, such restrictions may have an adverse effect on Nordic consolidation with regard to Clearing $\&$ Settlement. For example, the rule in the Swedish Companies Act that beneficial holders of Nominee Registered shares shall reregister the holdings to a temporary share holders register no less than 10 days prior to the General Meeting in order to be entitled to vote seems to be an obstacle for foreign investors in this respect (cf. the Companies Act Section 3, Clause 10a and 13).

Estonia: No further comments provided.

Latvia: No further comments provided.

Lithuania: No further comments provided. 
1e) Identification of laws and discussion of their implication and/or suggestions for improvements.

Finland: It can be argued that the practice where the rules of the exchange are officially approved by the public authorities (Ministry of Finance) makes the amendment of rules less flexible and thus the "time-to-market" of new practices longer (Note: the official approval of exchange rules appears not to be the case in other Nordic countries).

The interpretations by the Finnish Financial Supervision Authority (RATA) relating to supervision of Finnish insider dealing rules block efficient use of a commission (clearing) account for the settlement of transactions involving Finnish clients thereby driving up the cost of settlement. The commission account has been endorsed in law.

Iceland: i) The barriers to foreign investment mentioned in b) could be removed. This is however a political issue. ii) The act. No. 2/1995 mentioned in d) should be updated so it reflects current stock market regulation.

Norway: The rules governing the placements for pension funds are still limiting the amount of funds, which can be invested in equity and derivatives.

\section{Foreign investors}

The purpose of these questions was to estimate the level of foreign access and participation in the Nordic and Baltic Stock Market.

What was the number of remote stock exchange members in your exchange?

\begin{tabular}{|l|c|c|c|c|c|c|c|c|c|}
\hline From: & DK & DK2 & FI & IS & NO & SE & ES & LA & LI \\
\hline Nordic countries & 7 & 0 & 14 & 1 & 5 & 20 & 2 & - & 0 \\
\hline $\begin{array}{l}\text { Other European } \\
\text { countries }\end{array}$ & 9 & 0 & 14 & 0 & 8 & 25 & 1 & - & 0 \\
\hline Other countries & 0 & 0 & 0 & 0 & - & - & - & - & 0 \\
\hline
\end{tabular}

What was their $\%$ of total market turnover in 2003 ?

\begin{tabular}{|l|c|c|c|c|c|c|c|c|c|}
\hline From: & DK & DK2 & FI & IS & NO & SE & ES & LA & LI \\
\hline Nordic countries & 8.0 & 0 & 16.2 & 0 & 3.8 & 2.7 & 0.6 & - & - \\
\hline $\begin{array}{l}\text { Other European } \\
\text { countries. }\end{array}$ & 12.0 & 0 & 35.7 & - & 9.1 & 20.6 & 1.0 & - & - \\
\hline Other countries & 0 & 0 & 0 & - & - & - & - & - & - \\
\hline
\end{tabular}

What was the number of foreign companies listed in your exchange?

\begin{tabular}{|l|c|c|c|c|c|c|c|c|c|}
\hline From: & DK & DK2 & FI & IS & NO & SE & ES & LA & LI \\
\hline Nordic countries & 3 & 0 & 3 & 0 & 5 & 5 & - & - & 0 \\
\hline $\begin{array}{l}\text { Other European } \\
\text { countries. }\end{array}$ & 1 & 0 & 0 & 0 & 4 & 7 & - & - & 0 \\
\hline Other countries & 3 & 0 & 0 & 0 & 13 & 4 & - & - & 0 \\
\hline
\end{tabular}

What was the number of domestic companies that only have a foreign listing?

\begin{tabular}{|l|c|c|c|c|c|c|c|c|c|}
\hline In: & DK & DK2 & FI & IS & NO & SE & ES & LA & LI \\
\hline Nordic countries & 0 & 0 & - & 0 & - & - & - & - & 0 \\
\hline $\begin{array}{l}\text { Other European } \\
\text { countries. }\end{array}$ & 1 & 0 & - & 0 & - & - & - & - & 0 \\
\hline Other countries & 1 & 0 & - & 1 & - & - & - & - & 0 \\
\hline
\end{tabular}


a) Significant changes in the accessibility of foreign investors, members and companies to your market since 1999 ?

Denmark: Since 1999, when Stockholmsbörsen and the Copenhagen Stock Exchange started to use the same trading system - SAXESS - a significant number of international banks and investment firms have become members of the Copenhagen Stock Exchange. This has significantly improved the possibilities for foreign investors to trade Danish securities, because this can now be done easily and cheaply via their local member, cf. clearing and settlement below under section 5

Denmark2: No.

Finland: Centralisation of the Finnish depository system and launch of the new clearing and settlement system (HEXClear) has facilitated (both remote and local) access of foreign members to the Finnish CSD and settlement facilities.

Merger of OM and HEX and the consequential accession of HEX to NOREX as well as the introduction of a common trading system (SAXESS) facilitate foreign access to trading in Finnish securities.

Iceland: Yes, ICEX became a member of the NOREX alliance in 2000 and introduced a new trading system, SAXESS, to the market. The SAXESS system is used in all the NOREX exchanges, making it easier for investors to receive information about the market and to become active at any of the NOREX exchanges.

Norway: In 2002 Oslo Børs switched to the same trading platform as the Copenhagen Stock Exchange and Stockholmsbörsen. Since then a significant number of international banks and investment firms have become members of Oslo Børs. This has improved the possibilities for foreign investors to trade Norwegian securities, because this can now be done easily and cheaply via their local member.

Sweden: No.

Estonia: In October 2001 the Estonian Ministry of Finance enforced the new Securities Market Act, which significantly relieved the terms for cross-border listing and securities trading. After Estonia's accession into European Union in May 2004, the Investment Services Directive (ISD) will be enforced in Estonia.

Latvia: The RSE, since end-March, has made trading possible in EUR and USD as well. A security may be listed and traded only in one currency segment.

Lithuania: Under the Law on Investments, which entered into force on 30 of July 1999, foreign investment was prohibited in the following commercial-economic activities:

Guaranteeing state security and defence (except for investment by the foreign entities meeting the criteria of European and Transatlantic integration which Lithuania has opted for, provided this is approved of by the State Defence Council);

Production and sale of narcotic and psychotropic substances, non-medicinal highly effective or poisonous substances as well as cultivation, processing and sale of cultures containing narcotic, highly effective and poisonous substances;

Organization of lotteries. Since 1999 the Law was partly changed and now foreign investment is permitted in all spheres of economic and commercial activity with the ex- 
ception of the state security and defence sector (except investments made by foreign subjects meeting the criteria of Lithuania's European and transatlantic integration).

In the field of securities, the new Trading Rules of the National Stock Exchange of Lithuania (NSEL) that came into force on January 1, 2004 set forth the same requirements for both local and foreign intermediaries of public trading that seek NSEL membership. In accordance with paragraphs 4.2 and 370 of the Trading Rules only those intermediaries of public trading may become members of the NSEL that hold the right to provide investment services and the right to trade on the Stock Exchange. Foreign intermediaries' right to provide investment services in Lithuania is regulated by the Securities Market Law. This law distinguishes between the intermediaries of public trading licensed in EU Member States and other states. According to Article 23 of the Law on Securities Market of Republic of Lithuania, financial brokerage firms licensed in Member States of the EU may start providing investment services in Lithuania by establishing a branch or without establishing a branch. A financial brokerage firm licensed in a Member State of the EU may start providing investment services in Lithuania without establishing a branch in one month after the foreign supervisory authority communicated to the Securities Commission of Lithuania the programme of the firm's operations (provision 2 of Article 23).

According to Article 21 of the Law on Securities Market financial brokerage firms licensed in countries that are not members of the EU have to acquire licence to provide investment services. This licence is granted by the Securities Commission of Lithuania.

b) Unnecessary domestic obstacles still remaining for foreign investors to trade in domestic stock?

Denmark: The main obstacle today in international cross-border trading of equities is the lack of efficient cross-border clearing and settlement, cf. section 5 below.

Finland: There are no particular domestic problems. The main general obstacle is the lack of efficient cross-border clearing and settlement, see section 5 below.

Iceland: The main obstacle today in international cross-border trading of equities is the lack of efficient cross-border clearing and settlement.

Clearing and Settlement between foreign members of ICEX and the Icelandic Securities Depository (ISD) is a problem that has not yet been solved, i.e. foreign members are not able to clear and settle through ISD unless they are account operators or negotiate an agreement with an account operator. Another obstacle is that ISD requires an ID number for an account holder so the investor needs to apply for an Icelandic ID number to be able to open an ISD-account, that is, if the security is electronically registered. With few exceptions equities listed at ICEX are electronically registered as well as benchmark bonds and some other bonds.

Norway: The main obstacle today in trading of equities cross-border is the lack of efficient cross-border clearing and settlement, cf. section 5 a) below.

Sweden: The main obstacle today in trading of equities cross-border is the lack of efficient cross-border clearing and settlement, cf. section 5 below.

Estonia: None 
Latvia: There are no legal obstacles. The small size of the market and the small free float of the listed companies are the reasons why it is not cost-efficient to become a remote member.

Lithuania: None

\section{Competition}

The purpose of the following questions was to identify, what incentives or objections the Stock Exchanges may have toward or against further integration of the Nordic and Baltic Stock Market.

a) What geographic and/or functional area do you see as your competitive market?

Denmark: Competition in the exchange sector in general is global. For smaller exchanges in isolation, it may only be European, but through NOREX, all the Nordic exchanges are part of a major alliance and hence exposed to global competition.

On the functional side, the Copenhagen Stock Exchange is the only exchange in Denmark and there is only one authorised market place as a possible competitor.

Internalising is permitted in Denmark. The ratio of internalised trades versus trades done on the trading system is roughly $30: 70$

Denmark2: Small and medium-sized companies based in Denmark

Finland: The exchange offer trading in equities and derivatives today and derivative clearing services. These services are offered globally to intermediaries and issuers (customers) but are of foremost interest for customers with special interest in the Nordic and Baltic region.

Iceland: ICEX sees competition both inside and outside Iceland, but like often the threats present opportunities as well. The other markets of the Nordic region certainly compete with ICEX on a certain level but this is outweighed by the advantages of cooperation between the markets and for ICEX to be seen as a part of the Nordic region by the international investment community. Other small markets and emerging markets are also posing some competition to ICEX. Also, exchanges in similar time zones as Iceland are likely to be ICEX's competitors.

In general we see competition in the exchange sector to be global. For smaller exchanges in isolation, it may only be Europe, but through NOREX, all the Nordic exchanges are part of a major alliance and hence exposed to global competition.

Norway: Competition is global. For listing of securities the competition is to some extent depending on sector. Competition for attracting investors is global with US and UK as most important. Competition for attracting brokers/members is European due to US-law.

Sweden: The exchange offer trading in equities and derivatives today and derivative clearing services. These services are offered globally to intermediaries and issuers (customers) but are of foremost interest for customers with special interest in the Nordic region.

Estonia: Tallinn Stock Exchange is a part of OMHEX group.

Latvia: Riga Stock Exchange is a part of OMHEX group. 
Lithuania: On the domestic market, the NSEL competes with other sectors for capital, e.g., banking, leasing, real estate, etc. Geographically, the NSEL competes for foreign investment with other markets from Central and Eastern Europe, and more specifically, the markets of the Baltic region.

b) Do you consider transparency rules, e.g. how frequently listed companies must publish their financial reports etc., to affect your competitive status positively or negatively? Please describe.

Denmark: In today's globally competitive environment, transparency as well as other types of regulation, is it for issuers or intermediaries, must be set at an internationally acceptable level - it must be "best practice". There is no room for country specific rules. If your market is not at best practice, it will affect your competitive status negatively. The regulation on Copenhagen Stock Exchange is generally considered to be at the level of best practice.

Denmark2: Today we have a competitive advantage because our rules and demands are related to small and medium-sized companies, which means less strict than the rules and demands on Copenhagen Stock Exhange, our only competitor in Denmark.

Finland: Adequate level of transparency creates and supports market credibility and thus contributes positively to the competitive status of an exchange. However, there may be some cases that quarterly reporting could be inappropriate e.g. due to the segmentation of a particular market. We therefore urge that the frequency of financial reporting is not determined in law, not to mention EU law, rather it is up to the exchange to decide which frequency suits best its each market segment.

The differences in transparency rules will be mitigated to some extent through implementation of the Transparency Directive, although the frequency of the reports will not be harmonized.

Iceland: All rules that enhance better information disclosure and transparency are good for the market, however, it is important that rules are in line with other comparable markets, i.e. not country specific. More harmonisation of rules within both the Nordic region and Europe as a whole is viewed positively by ICEX as it tones down the Icelandic special features.

Norway: Transparency regarding Corporate Governance / company disclosures is important in order to maintain confidence to Oslo Børs as a fair market place. Today Oslo Børs is among the most transparent markets in the world regarding trading. European tendency, with implementing CCP's, is opposite - and need for anonymity must constantly be evaluated.

Sweden: Our experience is that the transparency requirements currently in place at Stockholmsbörsen affect our competitive status positively, by enhancing investor confidence for our markets.

Estonia: The reporting rules are in line with the internationally recognized practices, i.e. all listed companies must publish their quarterly reports and annual audited reports. All reports must be in line with the IAS requirements.

Latvia: No further comments provided.

Lithuania: We believe that transparency rules imposed on our listed companies positively affect our competitive status. Quarterly and interim reporting as well as efficient 
disclosure of the ad hoc information help to raise investor confidence in the companies listed on the NSEL. The NSEL has an electronic link with the issuers via a Web News system, which enables the companies to disclose material information efficiently and the NSEL to publish it immediately on the website of the Stock Exchange.

c) Is it possible to trade stocks in more than one currency in your exchange, Yes () Or No (), and do you see that as having a major impact on your competitive status?

Denmark: Yes (X), Any currency. It is potentially important in a competitive environment to be able to trade foreign securities in their home currency.

Denmark2: No, but we expect that it will be necessary to trade stocks in euro in the near future.

Finland: No (X). No major impact. Trading in EUR contributes positively to the competitive status.

Iceland: Yes (X), Yes, it is possible to trade in DKK and we are working towards being able to trade in EUR and USD, but this is a Clearing \& Settlement issue rather than a technical issue for ICEX. However, ICEX believes it is important to be able to offer listing and trading in foreign currencies, both with domestic and foreign issuers in mind.

Norway: Yes (X). Any currency. The demand for trading in foreign currencies has not yet been considerable. To have the ability to offer such trading, with effective crossborder settlement, can be important in future years.

Sweden: Yes (X), SEK, EUR. No. Not at the moment.

Estonia: No (X). Tallinn Stock Exchange trading currency is EUR.

Latvia: No (X). No.

Lithuania: No (X). No.

d) Do you see any threats to your competitive status or new possibilities in the changes that are happening and will be happening in the Nordic and/or European stock markets or legislation within the next few years?

Denmark: The merger between OM and HEX was accompanied by an invitation to the exchanges, CSD's and clearing houses in the other Nordic and Baltic countries to take part in the merger or enter into closer co-operation. Given the already existing cooperation in the NOREX alliance, this will most likely deepen even further. On the CSD side, co-operation is of utmost importance, cf. below under section 5.

The EU regulation following the Financial Services Action Plan is very extensive and detailed. There is a risk that too onerous and detailed regulation of the activities of exchanges may lead to a less innovative and hence competitive exchange sector.

Denmark2: Yes, we see some threats in the near future. The newest legislation will have an impact on our stock market, because the listed companies must live up to the same rules and demands as on the large stock markets. The companies listed on our Stock Exchange are small and medium-sized companies, and the new legislation means the administrative costs will be much higher for them than today. In some cases the costs will probably be too high compared to the advantages of being listed.

Finland: The consolidation in the Nordic countries, e.g. the recent merger between OM and HEX and the synergies derived from the NOREX alliance will facilitate cost effi- 
ciency and maintain the competitive advantage for the Nordic exchanges. Further the merger between OM and HEX can be seen as a catalyst for creation of cost efficiencies through out the transaction chain. However, the lack of a common Nordic Clearing \& Settlement facility in general, and a CCP in particular, could in a longer perspective diminish part of this advantage. The maintenance of five different currencies is in a narrow perspective to the advantage of the Nordic exchanges, but an impediment to the creation of an efficient Nordic Clearing \& Settlement solution in the long run.

EU legislation. The harmonisation of the securities legislation in the EU under FSAP is beneficial in the sense that it waters down at least some obstacles to create a level playing field on e.g. operating of trade matching facilities within the EU.

On the other hand, there is a definite risk that the number of details on both Level 1 and Level 2 as well as the shift from self-regulation to increased regulation and enforcement from the public authorities will likely result in too much "red tape" at the cost of efficiency and competitiveness for regulated entities or the markets as such. In this respect, it is imperative that the Level 2 regulations with regard to e.g. ISD II/FIMD take into sufficient account the different conditions under which regulated markets operate, e.g. with regard to market model. If not, this may lead to sub-optimal solutions from the Nordic and Baltic Exchanges' point of view.

The current tendency in the EU seems to be to regulate all regulated markets and listed companies in a substantially similar manner - this approach doesn't necessarily:

take into consideration the need for separation between the different market segments take into account the needs for the issuers / market participants / markets of different size

harmonise the best practices within given target

allow for flexible market development.

The current European legislative approach may thus lead to a too rigid regulatory framework for regulated markets and listed companies. For this reason it is certain that the Finnish regulatory framework for "non-regulated" markets needs to be enhanced in order to provide a supportive, flexible and up-to-date legal and regulatory framework for the development of less regulated markets. This means that also the tax laws have to be considered in this respect.

Iceland: ICEX views Nordic co-operation and further integration in the Nordic and Baltic region as a positive development and creating opportunities for the Exchange. Most of the foreseeable changes in the legal framework are considered an improvement for the market and ICEX believes that, even though it is a small exchange it has every opportunity to thrive in the future environment.

Implementation is very crucial. There is a definite risk that the number of details on both Level 1 and Level 2 as well as the shift from self-regulation to increased regulation and enforcement from the public authorities will likely result in too much "red tape" at the cost of efficiency and competitiveness for regulated entities or the markets as such. The maintenance of five different currencies is in a narrow perspective to the advantage of the Nordic exchanges, but an impediment to the creation of an efficient Nordic Clearing \& Settlement solution in the long run. 
Norway: EU regulation can be a threat to achieved efficiency - if tasks are divided among several authorities. Further development of the NOREX alliance can improve the efficiency and distribution power of the Norwegian securities market. In the coming years, initiatives to achieve efficiency gains regarding cross-border settlement should be given priority.

The competitiveness and efficiency in the Nordic securities markets is highly connected to the ability to create liquidity in local securities. The Exchanges have met this challenge by creating the Norex alliance with an aim to permit trading at lower cost and to create economic benefits for the exchanges' user groups by:

Offering investors a more efficient process of price determination by concentrating offers and bids from a larger number of investors.

Allowing investors to access the services of a significantly larger number of competing exchange members.

Reducing the cost of capital for issuers through better distribution and more efficient price determination.

Giving exchange members and investors access to all the products offered within the Alliance at lower cost.

This is done by:

The use of a joint trading system.

The promotion to use a single order book for each security ("single point of liquidity").

The promotion of cross membership.

A joint regulatory framework for membership and trading.

Oslo Børs sees the implementation of new EU directives as an opportunity to further harmonize rules and regulations in such a manner that customers are able to experience the Alliance as similar markets from an operational point of view, thus reducing compliance and regulatory costs for the investors. Although increased EU legislation itself means further harmonization within EU/EEA, it is important to further reduce legal differences in the Nordic countries. Rules on takeovers and investors' obligation to disclose major holdings are examples of areas where Nordic harmonization would increase efficiency.

Sweden: The consolidation in the Nordic countries, e.g. the recent merger between OM and HEX and the synergies derived from the NOREX alliance will facilitate cost efficiency and maintain the competitive advantage for the Nordic exchanges. Further the merger between OM and HEX can be seen as a catalyst for creation of cost efficiencies through out the transaction chain. However, the lack of a common Nordic Clearing \& Settlement facility in general, and a CCP in particular, could in a longer perspective diminish part of this advantage. The maintenance of five different currencies is in a narrow perspective to the advantage of the Nordic exchanges, but an impediment to the creation of an efficient Nordic C\&S solution in the long run.

The harmonisation of the securities legislation in the EU under FSAP is beneficial in the sense that it waters down at least some obstacles to create a level playing field on e.g. operating of trade matching facilities within the EU. 
On the other hand, there is a definite risk that the number of details on both Level 1 and Level 2 as well as the shift from self-regulation to increased regulation and enforcement from the public authorities will likely result in too much "red tape" at the cost of efficiency and competitiveness for regulated entities or the markets as such. In this respect, it is imperative that the Level 2 regulations with regard to e.g. ISD II/FIMD take into sufficient account the different conditions under which regulated markets operate, e.g. with regard to market model. If not, this may lead to sub-optimal solutions from the Nordic and Baltic Exchanges' point of view.

The current tendency in the EU seems to be to regulate all regulated markets and listed companies in a substantially similar manner - this approach doesn't necessarily:

take into consideration the need for separation between the different market segments take into account the needs for the issuers / market participants / markets of different size

harmonise the best practices within given target

allow for flexible market development.

The current European legislative approach may thus lead to a too rigid regulatory framework for regulated markets and listed companies

Estonia: The over-regulation of stock exchange in the context of the EU, especially for issuers, could lead to the possibility that the issuers find the benefits from listing lesser than the obligations and costs related to it.

Latvia: No threats are expected. Since autumn of 2003 the Riga Stock Exchange, as a part of OMHEX group, became a member of NOREX alliance; migration to SAXESS trading platform is expected to take place in the second half of 2004. Trading on common platform will facilitate the market access for members, and, consequently, investors.

Lithuania: Under the new version of the Company Law, which came into force on 1 of January 2004, it will be easier to reorganise public companies into private companies. Thus there is a threat that some public companies could decide to change their status into private. If it happens it will reduce the number of publicly traded companies and consequently may make an impact on a trade volume of the Stock Exchange. On the other hand, under the new version of the NSEL's Trading Rules since January 2004 issuers have a possibility to distribute their newly issued shares through the Stock Exchange. It is expected that this new service of the Stock Exchange will increase trade volumes of the exchange in the future. Moreover, since January 2004 foreign brokerage firms obtained the right to become members of the stock exchange. It is believed that this will also contribute to Lithuanian capital market and will open new possibilities to market participants, issuers and the exchange.

Please also see section 4. a) below. 


\section{Level of cooperation with other exchanges}

The purpose of these questions was to identify the level of cooperation between the Nordic and Baltic Stock Exchanges, and their cooperation with exchanges outside the Nordic-Baltic region. It was possible to answer regarding the following areas: Domes-

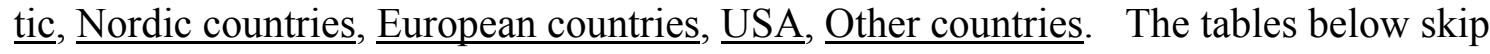
those areas that include no answers.

Joint trading systems?

\begin{tabular}{|l|l|l|l|l|l|l|l|l|}
\hline & DK & FI & IS & NO & SE & ES & LA & LI \\
\hline Nordic & Yes & Yes $*$ & Yes & Yes & $\begin{array}{l}\text { Same by } \\
09 / 2004\end{array}$ & Yes ** & - & No \\
\hline Other & & $\begin{array}{l}\text { Yes Currently } \\
\text { Estonia, Latvia } \\
\text { by 9/2004** }\end{array}$ & & & $\begin{array}{l}\text { Estonia and } \\
\text { Latvia by } \\
09 / 2004\end{array}$ & & - & \\
\hline
\end{tabular}

* FI: The same trading system in use in all Nordic countries by $9 / 2004$.

**ES: Currently common trading system with HEX Helsinki. In 2003 Tallinn Stock Exchange will implement SAXESS trading system, used by NOREX markets.

Ownership of your exchange is?

\begin{tabular}{|c|c|c|c|c|c|c|c|c|c|}
\hline & DK & DK2 & FI & IS & NO & SE & ES & LA & LI \\
\hline Domestic & Yes & Yes & Yes* & Yes & Yes & OMHEX & $38 \%$ & $7 \%$ & Yes \\
\hline Nordic & & & Yes* & & & & $\begin{array}{l}\mathbf{6 2 \%} \\
\text { OM } \\
\text { HEX } \\
\end{array}$ & $\begin{array}{l}\mathbf{9 3 \%} \\
\text { OM } \\
\text { HEX }\end{array}$ & \\
\hline European & & & & & Yes & & & & \\
\hline USA & & & & & Yes & & & & \\
\hline
\end{tabular}

*Finland: Domestic: HEX Integrated Markets Ltd (a holding company) owns HEX Helsinki holding the stock exchange licence. Nordic: OMHEX AB (publ.), a Swedish listed company owns HEX Integrated Markets Ltd.

Does any of the major owners of your exchange also operate or own other exchanges or related organizations?

\begin{tabular}{|l|l|l|}
\hline DK & Domestic & $\begin{array}{l}\text { No organisations exist, but as men- } \\
\text { tioned internalisation is permitted } \\
\text { and does exist }\end{array}$ \\
\hline DK2 & Yes, also part owner of CSE & \\
\hline FI & & $\begin{array}{l}\text { Stockholm, Tallinn and Riga Stock Exchanges; } \\
\text { Helsinki, Tallinn and Riga CSD's }\end{array}$ \\
\hline IS & No & \\
\hline NO & & $\begin{array}{l}\text { Helsinki, Tallinn, Riga Stock Exchanges and re- } \\
\text { spective CSD's, }\end{array}$ \\
\hline SE & & $\begin{array}{l}\text { OMHEX Group is a member of NOREX alliance } \\
\text { and has cooperation projects with other European } \\
\text { securities markets }\end{array}$ \\
\hline ES & & $\begin{array}{l}\text { Helsinki exchanges, Finnish CSD, HEX Tallinn, } \\
\text { Stockholmsbörsen }\end{array}$ \\
\hline LA & & \\
\hline LI & No & \\
\hline
\end{tabular}




\section{Other cooperation}

\begin{tabular}{|c|c|c|}
\hline & Nordic & European \\
\hline DK & $\begin{array}{l}\text { Amongst the NOREX exchanges there is co-operation } \\
\text { on other IT related issues: web, DWH, indices, data } \\
\text { feed distribution system }\end{array}$ & \\
\hline FI & & $\begin{array}{l}\text { Cooperation with Eurex with } \\
\text { respect to Finnish derivatives } \\
\text { traded on Eurex }\end{array}$ \\
\hline \multicolumn{3}{|l|}{ IS } \\
\hline NO & Surveillance systems, Indices, WEB & \\
\hline SE & $\begin{array}{l}\text { Trading and clearing link with regard to derivatives } \\
\text { with the Norwegian and Danish markets }\end{array}$ & $\begin{array}{l}\text { Trading and clearing link } \\
\text { with regard to derivatives } \\
\text { with EDX and LCH (UK) }\end{array}$ \\
\hline ES & $\begin{array}{l}\text { In addition to group-level co-operation projects, Tallinn } \\
\text { Stock Exchange and Riga Stock Exchange have ongo- } \\
\text { ing further integration projects into joint Baltic market }\end{array}$ & \\
\hline \multicolumn{3}{|l|}{ LA } \\
\hline LI & Yes & yes \\
\hline
\end{tabular}

a) Do you expect increased cooperation or mergers, including vertical integration, within the European stock market within the next few years?

Denmark: As mentioned, increased co-operation should be expected in the Nordic region. It is not unlikely that consolidation will go further also in the rest of the EU.

Denmark2: Yes, I think we will see increased cooperation between the Nordic Stock Exchanges.

Finland: Yes. There will be further cooperation and consolidation in the trading as well as the clearing and settlement area in the European region. This competition will spill over to the Nordic region as well. A long-term competitive Nordic alternative would imply consolidation in trading as well as clearing settlement. For the Nordic region it is important to evaluate the economic effects of having an efficient exchange and financial infrastructure for long-term creation / development of supplying risk capital and supporting GNP.

On the trading level, horizontal integration is close to be finalized, either by way of mergers (OM and HEX) or co-operation (NOREX). Similar co-operation are in place also with regard to settlement, even though the co-operation on that level only is framed in the form of bilateral FOP-links (inter alia of ECSDA type). It could be expected that the Nordic market within a few years time will have in place a CCP, like most of the other EU-markets. Further cost efficiencies could be obtained by vertical integration and also by supporting cross border trading in the Nordic region. These efficiencies would be reached in the technical cooperation / sharing of systems and by economies of scale.

In conclusion, it is anticipated that further integration will take place in a few years time, but the forms for such integration is hard to predict.

Iceland: Yes. There will be further cooperation and consolidation in the trading as well as the clearing and settlement area in the European region. This competition will spill over to the Nordic region as well. A long-term competitive Nordic alternative would 
imply consolidation in trading as well as Clearing \& Settlement. For the Nordic region it is important to evaluate the economic effects of having an efficient exchange and financial infrastructure for long-term creation / development of supplying risk capital and supporting GNP. On the trading level, horizontal integration is close to be finalized, either by way of mergers (Stockholmsbörsen-Helsinki Exchanges) or co-operation (NOREX). It could be expected that the Nordic market within a few years time will have in place a CCP, like most of the other EU-markets. Further cost efficiencies could be obtained by vertical integration also supporting cross-border trading in the Nordic region. These efficiencies would be reached in the technical cooperation / sharing of systems and by economies of scale. In conclusion, it is anticipated that further integration will take place in a few years time, but the form for such integration is hard to predict.

Norway: Mergers and cooperation among exchanges will continue. Local CSD's should seek mergers and alliances, with exchanges and/or CSD's, in order to improve efficiency and competitiveness towards global/European CSD's.

Sweden: Yes. There will be further cooperation and consolidation in the trading as well as the clearing and settlement area in the European region. This competition will spill over to the Nordic region as well. A long-term competitive Nordic alternative would imply consolidation in trading as well as Clearing \& Settlement. For the Nordic region it is important to evaluate the economic effects of having an efficient exchange and financial infrastructure for long-term creation / development of supplying risk capital and supporting GNP. On the trading level, horizontal integration is close to be finalized, either by way of mergers (Stockholmsbörsen-Helsinki Exchanges) or co-operation (NOREX). Similar co-operation are in place also with regard to settlement, even though the co-operation on that level only is framed in the form of bilateral FOP-links (inter alia of ECSDA type). It could be expected that the Nordic market within a few years time will have in place a CCP, like most of the other EU-markets. Further cost efficiencies could be obtained by vertical integration also supporting cross-border trading in the Nordic region. These efficiencies would be reached in the technical cooperation / sharing of systems and by economies of scale. In conclusion, it is anticipated that further integration will take place in a few years time, but the form for such integration is hard to predict.

Estonia: Tallinn Stock Exchange is a part of OMHEX group.

Latvia: Riga Stock Exchange is a part of OMHEX group.

Lithuania: The National Stock Exchange of Lithuania (NSEL) is currently undergoing privatisation. The NSEL shares owned by the state will be sold by way of a public tender in a joint stake with the shares held by private shareholders. The initial sale price of the $54.47 \%$ NSEL stake is LTL 3.35 million. Concurrently, a $32 \%$ state-owned holding of the Central Securities Depository of Lithuania (CSDL) will be sold; the initial sale price of the stake amounts to LTL 4.1 million. Bids of potential buyers-strategic investors will be accepted during March 4 and 5, 2004. Review of the proposal documents submitted by potential buyers-strategic investors will start on March 5, 2004.

The main aim of this privatisation is to integrate the domestic securities market in the single European market and, in this way, ensure successful development of the Lithuanian securities market. The integration of stock exchanges across the border will be achieved by way of joining trading and clearing systems. Moreover, the CSDL may be 
integrated in one group in the future (for a while, the Bank of Lithuania is planning to retain control over $60 \%$ of CSDL shares).

The two potential buyers of the NSEL and CSDL stakes are OMHEX and the Warsaw Stock Exchange (in possible co-operation with Euronext).

\section{Clearing and Settlement}

The purpose of these questions was to clarify the basic difference between the clearing and settlement rules of the Stock Exchanges and how it affects their competitive status.

a) How do you estimate that your clearing and settlement system affects your competitive status? Is it joint ( ) or separate ( ) from the clearing and settlement systems that other stock exchanges in related markets use? Please comment on how your clearing and settlement system affects your competitive status?

Denmark: Separate: Trading across borders - also in the Nordic region - is easy and simple. Most of the bigger exchange members are members of several exchanges. In the Nordic area, 33 members are members of more than one exchange.

The difficult and expensive part of a trade is the subsequent clearing and settling of it.

There are still 5 different CSD's in the Nordic region, one in each country. There are some FOP-links (Free Of Payment), but the lack of DVP-links (Delivery Versus Payment) is a big problem. This means that any member, wishing to become a member of another exchange, must either become a member of the local clearing and settlement scenario or sign an agreement with a local member to clear and settle for him. This is expensive.

The lack of efficient cross-border clearing and settlement is the single biggest competitive challenge for the Nordic region. A common clearing and settlement system - like the common trading system SAXESS - would be of extreme importance for the competitive situation of the Nordic region.

Also, the Nordic region will soon be the only part of Europe without a CCP function. A $\mathrm{CCP}$ - Central Counter Party - removes the counterparty risk between the two parties to a trade. It also allows for completely anonymous trading and gives the members the possibility to net all their trades in any given security. And most importantly it makes it easier to clear and settle trades across borders. Today, a CCP function is a de facto market standard, and it is a serious threat to the competitive situation in the Nordic region, that it has not yet been possible to agree to set up such a function.

However, it should be stressed, that these issues should be solved by the relevant practitioners in the Nordic countries.

Denmark2: Separate: We allow private customers as members of our Stock Exchange, and if a trade is between two members, clearing and settlement will be real time. That gives us a competitive advantage.

Finland: Separate: Clearing \& Settlement takes place within the same group in Finland, Estonia and Latvia. In the overall market perspective it strengthens the market competitiveness by providing possibilities for integrated trading solutions and by enabling direct market-wide development and management of the full value chain. We see that by combining all infrastructure services of the Finnish, Estonian and Latvian secu- 
rities market chain under one roof, we have been able to offer more effective services to the customers both in the home country and abroad. The chosen structure also provides more flexibility and enhances the ability of the market infrastructure to react to changes at a faster pace. We feel it is justified to state that the vertical group structure has facilitated, not hindered cross-border investment.

On a more general level it can be said that trading across borders - also in the Nordic region - is easy and simple. Most of the bigger exchange members are members of several exchanges. However, the most complicated and expensive part of a trade is the subsequent clearing and settling of it.

There are still five different CSD's in the Nordic region, one in each country; and there is no operational DVP-links nor standard technology between them. This means that any member, wishing to become a member of another exchange, must either become a member of the local clearing and settlement system or use a local settlement agent to clear and settle for him.

The lack of efficient cross-border clearing and settlement is the single biggest competitive challenge for the Nordic region. A common clearing and settlement system - like the common trading system SAXESS - would be of extreme importance for the competitive situation of the Nordic region.

Also, the Nordic region will soon be the only part of Europe without a CCP function. A $\mathrm{CCP}$ would inter alia facilitate simplified clearing and settlement of trades across borders. Today, a CCP function is a de facto market standard, and it is a serious threat to the competitive situation in the Nordic region, that it has not yet been possible to agree to set up such a function.

However, it should be stressed, that these issues should be solved by the relevant practitioners in the Nordic countries.

Iceland: Separate: The Icelandic Securities Depository (ISD) is the clearing system for all listed securities apart from listed Faroese bonds. It is mostly separate from other systems although it has a link to Værdipapircentralen (VP) in Denmark. The listed Faroese bonds are cleared and settled in Denmark via VP.

There is no doubt in our minds that ICEX's competitive status would improve if the local clearing and settlement system was more integrated to clearing and settlement systems in other countries. A most important first step would be the further integration of clearing and settlement systems in the NOREX countries.

There are still 5 different CSD's in the Nordic region, one in each country; and there is almost no operational link between them. This means that any member, wishing to become a member of another exchange, must either become a member of the local clearing and settlement scenario or sign an agreement with a local member to clear and settle for him. This is expensive.

The lack of efficient cross-border clearing and settlement is the single biggest competitive challenge for the Nordic region. A common clearing and settlement system - like the common trading system SAXESS - would be of extreme importance for the competitive situation of the Nordic region.

Also, the Nordic region will soon be the only part of Europe without a CCP function. A $\mathrm{CCP}$ - Central Counter Party - removes the counterparty risk between the two parties to 
a trade. It also allows for completely anonymous trading and gives the members the possibility to net all their trades in any given security. And most importantly it makes it easier to clear and settle trades across borders. Today, a CCP function is a de facto market standard, and it is a serious threat to the competitive situation in the Nordic region, that it has not yet been possible to agree to set up such a function. However, it should be stressed, that these issues should be solved by the relevant practitioners in the Nordic countries.

Norway: Separate: Cross-border settlement is the most expensive part related to trading across borders. CSD-systems have not been harmonized to the same extent as exchanges have and in the Nordic region there is specifically need for a $\mathrm{CCP}$ offering one matching cycle (linking exchange and CSD) and hence reduced costs, reduced counterparty risk and anonymous trading.

Sweden: Separate: Trading across borders - also in the Nordic region - is easy and simple. Most of the bigger exchange members are members of several exchanges. However, the most complicated and expensive part of a trade is the subsequent clearing and settling of it.

There are still five different CSD's in the Nordic region, one in each country; and there is no operational DVP-links nor standard technology between them. This means that any member, wishing to become a member of another exchange, must either become a member of the local clearing and settlement system or use a local settlement agent to clear and settle for him.

The lack of efficient cross-border clearing and settlement is the single biggest competitive challenge for the Nordic region. A common clearing and settlement system - like the common trading system SAXESS - would be of extreme importance for the competitive situation of the Nordic region.

Also, the Nordic region will soon be the only part of Europe without a CCP function. A CCP would inter alia facilitate simplified clearing and settlement of trades across borders. Today, a CCP function is a de facto market standard, and it is a serious threat to the competitive situation in the Nordic region, that it has not yet been possible to agree to set up such a function. However, it should be stressed, that these issues should be solved by the relevant practitioners in the Nordic countries.

Estonia: Separate: Tallinn Stock Exchange's vertical ownership structure (i.e. stock exchange is the full owner of CSD) enables better co-operation and solutions for the market participants.

Latvia: Separate:

Lithuania: Separate: The Central Securities Depository of Lithuania (CSDL) and the Bank of Lithuania (BoL) carry out clearing and settlement operations on our market. The depository system is fully dematerialized, and securities movements are recorded by relevant book entries in the securities accounts. Each issue is granted an ID code according to ISIN standards. Clearing and settlement procedures in general comply with ISSA and ECB recommendations. We believe that current clearing and settlement system provided by the CSDL and BoL affect our competitive status favorably. 
b) What is the clearing and settlement rule on your Stock Exchange?

\begin{tabular}{|c|c|c|c|c|}
\hline & $\mathrm{T}+1$ & $\mathrm{~T}+2$ & $\mathrm{~T}+3$ & Other? \\
\hline Denmark & & & $X$ & \\
\hline Denmark2 & & & $X$ & $\begin{array}{l}\text { Real time clearing and } \\
\text { settlement }\end{array}$ \\
\hline Finland & & & $\mathrm{X}$ & \\
\hline Iceland & $X$ & & & $\begin{array}{l}\text { Except Faroese bonds } \\
\text { which are settled at } \mathrm{T}+3 \\
\text { (their clearing system is } \\
\text { VP and not ISD) }\end{array}$ \\
\hline Norway & & & $\mathrm{X}$ & \\
\hline Sweden & & & $\mathrm{X}$ & \\
\hline Estonia & & & $\mathrm{X}$ & $\begin{array}{l}\text { The default settlement } \\
\text { rule is } \mathrm{T}+3 \text {. However, for } \\
\text { settlement of negotiated } \\
\text { deals the members can } \\
\text { agree on settlement rule } \\
\mathrm{T}+1 \text { to } \mathrm{T}+6 \text {. }\end{array}$ \\
\hline Latvia & & & $X$ & $\begin{array}{l}\mathrm{T}+0 \text { to } \mathrm{T}+40 \text { possible for } \\
\text { negotiated trades }\end{array}$ \\
\hline Lithuania & $\begin{array}{l}\text { For gov- } \\
\text { ernment } \\
\text { securities }\end{array}$ & & $\begin{array}{l}\text { For shares and } \\
\text { debt securities } \\
\text { other than gov- } \\
\text { ernment }\end{array}$ & $\begin{array}{l}\mathrm{T}+0 \text { to } \mathrm{T}+5 \text { for negoti- } \\
\text { ated deals (direct transac- } \\
\text { tions) }\end{array}$ \\
\hline
\end{tabular}

c) How does the clearing and settlement rule above affect your competitive status?

Denmark: Most markets use $\mathrm{T}+3$. It does not seem to be a competitive issue at the moment.

Denmark2: See above.

Finland: No major impact.

Iceland: ICEX believes that this short settlement schedule has a negative effect on its competitive status for two reasons. First, and most important, currency settlement takes place at $\mathrm{T}+2$. Second, the convention in most other markets is $\mathrm{T}+2$ or $\mathrm{T}+3$. For these reasons, $\mathrm{T}+1$ is likely to limit the participation of foreign investors in the Icelandic market although the impact is hard to quantify.

Norway: $\mathrm{T}+3$ is market standard. US are moving towards real-time settlement, but $\mathrm{T}+1$ seems to be the target. More important than the number of settlement days is the move towards straight through processing with a low proportion of manually handled settlement.

Sweden: No major impact. 
Estonia: The settlement rule is based on internationally recognized standards and familiar to foreign market participants. Thus it should have a positive effect on the competitive status of Tallinn Stock Exchange.

Latvia: The rule is the same as practiced in most of the markets worldwide.

Lithuania: The above rule is widely accepted and complies with international standards. Therefore it has a positive impact on our competitive status.

In January 2004, CSDL implemented a project with the BoL on multi-batch and realtime securities and cash settlement. Alongside with the Payment System LITAS (launched by the BoL), CSDL started operating the new Securities Settlement System (SSS), which allows settlements both in real and designated time and ensures a simultaneous, final and irrevocable settlement of securities. The purpose of the SSS is to carry out registration, safekeeping of securities, execute stock events and settlements between participants by making transfers between general securities accounts and by submitting related payment orders into the LITAS. The participants of LITAS and SSS (commercial banks, financial brokerage firms, etc.) can manage liquidity, place and receive payment orders and carry out securities settlement in real time through a uniform messaging subsystem, using ISO 15022XML standard and IBAN.

d) Please describe shortly how a foreign investor would most likely or in practice trade in your Stock Exchange.

Denmark: Before 1999, a foreign institutional investor would most likely ask his local member to buy Danish securities. This local member would ask a Danish member to do the trade at the Copenhagen Stock Exchange, thereby inflicting two times commission on the foreign investor, plus clearing and settlement costs, cf. above.

Today, because of the significant number of remote members, a foreign institutional investor may still ask his local member to do the trade, but the local member may also be a member of the Copenhagen Stock Exchange and can do the trade directly itself, which makes it cheaper for the foreign investor. The increasing number of internet members offer private investors the possibility to trade foreign securities from their home.

Denmark2: A foreign investor will either become a member of our Stock Exchange or trade through a Danish bank or broker.

Finland: Either by using the current CSD links, where they exist (Sweden, Germany, France, the Netherlands) or by using services of a local custodian for clearing, settlement and custody purposes. There is substantial increase in the interest for direct remote access to the clearing and settlement system thereby increasing the probability of foreign remote members in the CSD system.

The market participants in Finland, together with HEX Integrated Markets, have drafted a guideline for foreign investors and participants on settlement on the Finnish market (see Market Practice for Securities Settlement 2003 - 2004, http://www.hex.com/en/settlement/index.html) explaining the local processes and thus facilitating operations of foreign members and investors in the market.

Iceland: A foreign investor is most likely to trade through an Icelandic member (and participation of this sort is considerable in the bond market). Direct participation of for- 
eign members has so far been minimal and there is only one foreign member (Nordea Bank Danmark A/S).

Norway: A US or UK investor would usually place an order through a UK member. Oslo Børs has an increased proportion of remote members (members located outside Norway), and those will usually enter the order directly into Oslo Børs' trading system. If the order is huge, the UK member will either try to find a counterparty among their own clients - and then report the trade to Oslo Børs, or they will use some of the large Norwegian brokers in order to place the order.

Sweden: [Either by becoming a member of the CSD (VPC) or by entering in to a commercial agreement for a custody link, covering settlement and custody.]

An investor that is an investment firm: It is expected that such an investor would apply for remote membership at Stockholmsbörsen, but settle its trades by using a local settlement agent that is a member of VPC. It is also expected that such an investor would use local members with knowledge of the Scandinavian markets for some of its trades. Assuming that the trades are proprietary, the holdings would normally be nominee registered in the VPC-system, and consequently, for the purposes of PRIMA, registered with the custodian normally used by the investor (which could be the settlement agent at VPC or someone else).

A professional investor that is not an investment firm: It is expected that such an investor would trade through the securities firm, which it normally uses for trading in equities, which could or could not be a member of Stockholmsbörsen. The holdings would probably be registered in the register where such investor normally registers its holdings. If facilitated by a link agreement between VPC and another national or international CSD, a transfer could be made directly between such CSD's, without a need to be converted through the books of a custodian bank.

Estonia: Via Tallinn Stock Exchange remote member or via Tallinn Stock Exchange local member.

Latvia: A foreign investor would select a Riga Stock Exchange member to act as a broker and custodian, open a securities account with it, and place buy/sell orders. Global custodians use local financial institutions as sub-custodians for securities held by their clients.

Lithuania: A buyer and/or seller of securities may participate in exchange trading only through an Exchange member, a financial brokerage firm (FBF) or a bank authorized by the Board of the Stock Exchange to take part in trading. Any national or foreign natural or legal person may become a client of an FBF or bank. Upon signing an account management contract with a firm or bank, a cash account and a securities account are opened for a client. Buying, selling, or transfer of securities by placing orders with brokers of an FBF or bank chosen by a client may be launched right upon tendering money to the cash register or transferring a respective amount of cash or securities to the account. Trading over internet is currently offered by four members. 


\section{Contact persons for further information}

\begin{tabular}{|c|c|c|c|c|}
\hline Country & Name & Status & Email & Telephone \\
\hline Denmark & P.E. Skaanning-Jørgensen & Senior Vice President & ps@,cse.dk & +4533933366 \\
\hline Denmark2 & Thomas Andersen & Manager & ta@danskamp.dk & +4570227228 \\
\hline Finland & $\begin{array}{l}\text { a) Tommi Toivola } \\
\text { b) Olli Lauri- } \\
\text { la }\end{array}$ & $\begin{array}{l}\text { Vice President, Cash Markets } \\
\text { Legal Council, Legal Unit }\end{array}$ & $\begin{array}{l}\text { tommi.toivola@hex.fi } \\
\text { olli.laurila@hex.fi }\end{array}$ & +3589616671 \\
\hline Iceland & Hrefna Sigfinnsdóttir & Head of Listing & hrefna.sigfinnsdottir@,icex.is & +3545252869 \\
\hline Norway & Kristoffer Sønnervik & $\begin{array}{l}\text { Client Relations - Institutional inves- } \\
\text { tors }\end{array}$ & ks@,oslobors.no & $\begin{array}{l}+4722341726 \\
+4741684486\end{array}$ \\
\hline Sweden & $\begin{array}{l}\text { Claes Urban Dackberg } \\
\text { b) Mats Beckman }\end{array}$ & $\begin{array}{l}\text { Acting head of Products and Markets, } \\
\text { Cash Market } \\
\text { Chief Legal Council }\end{array}$ & $\begin{array}{l}\text { Claes urban.dackberg } \\
\text { @, stockholmsborsen.se } \\
\text { mats.beckman } \\
\text { @, stockholmsborsen.se }\end{array}$ & +084056000 \\
\hline Estonia & Kristi Kolk & Marketing Manager & kristi.kolk@hex.ee & +3726408864 \\
\hline Latvia & Inese Purgaile & International Relations Manager & inese.purgaile@,rfb.lv & +3717212431 \\
\hline Lithuania & Arminta Saladziene & Director, Marketing and International & Arminta@nse.lt & +37052723277 \\
\hline
\end{tabular}




\section{Appendix B - Basic data}

Basic Data about Stock market

\begin{tabular}{|c|c|c|c|c|c|c|c|c|c|}
\hline & $\mathrm{DK}$ & DK2 & $\overline{\text { FI }}$ & IS & $\mathrm{NO}$ & $\mathrm{SE}$ & ES & $\overline{L A}$ & $\overline{\mathrm{LI}}$ \\
\hline $\begin{array}{l}\text { Number of compa- } \\
\text { nies listed on } 31 \\
\text { Dec } 2003\end{array}$ & 194 & 9 & 145 & 48 & 178 & 282 & 14 & 56 & 45 \\
\hline $\begin{array}{l}\text { Number of new } \\
\text { companies listed in } \\
2003\end{array}$ & 2 & 2 & 1 & 2 & 5 & 5 & 0 & - & 6 \\
\hline $\begin{array}{l}\text { Number of compa- } \\
\text { nies delisted in } \\
2003\end{array}$ & 9 & 0 & 5 & 18 & 30 & 20 & 0 & 6 & 7 \\
\hline $\begin{array}{l}\text { Total turnover in } \\
\text { the year } 2003, \text { bil- } \\
\text { lion euros }\end{array}$ & 56 & 0.006 & 145 & 6.2 & 66 & 270 & 0.502 & 0.125 & 0.172 \\
\hline $\begin{array}{l}\text { Total turnover in } \\
\text { the year } 2002 \text {, bil- } \\
\text { lion euros }\end{array}$ & 53 & 0.002 & 187 & 3.6 & 61 & 295 & 0.267 & 0.187 & 0.188 \\
\hline $\begin{array}{l}\text { Turnover rate } \\
\text { (turnover velocity) } \\
\text { in } 2003\end{array}$ & 0.58 & & 1.01 & 0.95 & 0.98 & 1.25 & 0.16 & 0.14 & 0.04 \\
\hline $\begin{array}{l}\text { Number of trading } \\
\text { days in } 2003\end{array}$ & 249 & 250 & 250 & 246 & 250 & 249 & 252 & 251 & 254 \\
\hline
\end{tabular}

Equity Turnover 2003 (billion euros).

\begin{tabular}{|l|l|l|l|l|l|l|l|l|l|}
\hline & DK & DK2 & FI & IS & NO & SE & ES & LA & LI \\
\hline Top 5 & 33 & 0.003 & 126 & 2.9 & 36 & 105 & 0.470 & 0.096 & 0.059 \\
\hline Top 10 & 42 & $\mathrm{n} / \mathrm{a}$ & 133 & 4.5 & 47 & 154 & 0.487 & 0.118 & 0.096 \\
\hline Top 15 & 47 & $\mathrm{n} / \mathrm{a}$ & 136 & 5.1 & 54 & 194 & 0.488 & 0.000 & 0.123 \\
\hline Total & 56 & 0.006 & 145 & 6.2 & 66 & 270 & 0.488 & 0.125 & 0.172 \\
\hline $\begin{array}{l}\text { Main list (if di- } \\
\text { vided) }\end{array}$ & & & 145 & 6.1 & & 231 & 0.478 & 0.066 & 0.054 \\
\hline $\begin{array}{l}\text { Secondary list(s) } \\
\text { (if divided OR if } \\
\text { separate from main } \\
\text { list?) }\end{array}$ & & & 0.2 & 0.1 & & 38 & 0.009 & 0.053 & 0.111 \\
\hline
\end{tabular}


Percentage of total stock turnover.

\begin{tabular}{|l|l|l|l|l|l|l|l|l|l|}
\hline & DK & DK2 & FI & IS & NO & SE & ES & LA & LI \\
\hline Top 5 & 59 & 49 & 87 & 48 & 54 & 39 & 94 & 76 & 34 \\
\hline Top 10 & 75 & - & 92 & 73 & 71 & 57 & 97 & 94 & 56 \\
\hline Top 15 & 84 & - & 94 & 83 & 82 & 72 & 97 & & 72 \\
\hline Total & 100 & & 100 & 100 & 100 & 100 & 97 & & 100 \\
\hline $\begin{array}{l}\text { Main list (if di- } \\
\text { vided) }\end{array}$ & & 100 & 98 & & 86 & 95 & 53 & 31 \\
\hline Secondary list(s) & & & 0 & 2 & & 14 & 2 & 42 & 64 \\
\hline
\end{tabular}

Market value 31 Dec 2003 (billion euros).

\begin{tabular}{|l|l|l|l|l|l|l|l|l|l|}
\hline & DK & DK2 & FI & IS & NO & SE & ES & LA & LI \\
\hline Top 5 & 43.2 & 0.3 & 91.7 & 3.83 & 52.4 & 71.3 & 0.785 & 1.238 & 2.836 \\
\hline Top 10 & 63.1 & - & 122.1 & 5.07 & 60.0 & 123.6 & 0.856 & 1.561 & 2.957 \\
\hline Top 15 & 71.2 & - & 128.9 & 5.66 & 64.3 & 150.1 & 0.000 & 2.003 & 3.005 \\
\hline Total & 96.4 & 0.3 & 157.8 & 7.34 & 81.9 & 257.0 & 0.903 & 4.227 & 3.005 \\
\hline $\begin{array}{l}\text { Main list (if di- } \\
\text { vided) }\end{array}$ & & & 156.7 & 6.61 & & 199.0 & 0.645 & 0.713 & 2.879 \\
\hline $\begin{array}{l}\text { Secondary list(s) } \\
\text { (if divided OR if } \\
\text { separate from main } \\
\text { list?) }\end{array}$ & & & 1.1 & 0.74 & & 56.8 & 0.203 & 2.069 & 0.125 \\
\hline
\end{tabular}

Number of trades (thousand)

\begin{tabular}{|l|l|l|l|l|l|l|l|l|l|}
\hline & DK1 & DK2 & FI & IS & NO & SE & ES & LA & LI \\
\hline Top 5 & 671 & n/a & 2,540 & 29.0 & 676 & 2,700 & 18.56 & 10.27 & 17.76 \\
\hline Top 10 & 1,044 & $\mathrm{n} / \mathrm{a}$ & 2,859 & 40.0 & 1,088 & 3,800 & 20.69 & 15.19 & 26.82 \\
\hline Top 15 & 1,278 & $\mathrm{n} / \mathrm{a}$ & 3,030 & 46.6 & 1,372 & 5,000 & 21.73 & 0.00 & \\
\hline Total & 1,918 & $\mathrm{n} / \mathrm{a}$ & 3,680 & 59.6 & 2,348 & 9,400 & 21.74 & 19.89 & 65.18 \\
\hline $\begin{array}{l}\text { Main list (if di- } \\
\text { vided) }\end{array}$ & & & 3,603 & 59.0 & 0 & 6,900 & 19.34 & 5.72 & 17.07 \\
\hline $\begin{array}{l}\text { Secondary list(s) } \\
\text { (if divided OR if } \\
\text { separate from main } \\
\text { list?) }\end{array}$ & & & 77 & 0.6 & 0 & 2,500 & 2.39 & 9.81 & 45.52 \\
\hline
\end{tabular}


Turnover rate $(\%)$

\begin{tabular}{|l|l|l|l|l|l|l|l|l|l|}
\hline & DK & DK2 & FI & IS & NO & SE & ES & LA & LI \\
\hline Top 5 & 76 & 1 & 137 & 114 & - & 147 & 16 & 12 & 5 \\
\hline Top 10 & 66 & - & 109 & 109 & - & 125 & 16 & 14 & 6 \\
\hline Top 15 & 66 & - & 105 & 104 & - & 129 & 16 & 0 & 6 \\
\hline Total & 58 & 2 & 92 & 95 & 98 & 125 & 16 & 14 & 4 \\
\hline $\begin{array}{l}\text { Main list (if di- } \\
\text { vided) }\end{array}$ & & 92 & 105 & & 138 & 16 & 10 & 8 \\
\hline $\begin{array}{l}\text { Secondary list(s) } \\
\text { (if divided OR if } \\
\text { separate from main } \\
\text { list?) }\end{array}$ & & & 18 & 17 & & 78 & 7 & 26 & 5 \\
\hline
\end{tabular}

Stock Exchange Members' Share in Equity Turnover 2003 (billion euro).

\begin{tabular}{|l|l|l|l|l|l|l|l|l|l|}
\hline & DK & DK2 & FI & IS & NO & SE & ES & LA* & LI \\
\hline Top 5 & 63 & - & 45 & 10,2 & 61 & 109 & - & 0,101 & 0,478 \\
\hline Top 10 & 85 & - & 77 & 11,8 & 98 & 172 & - & 0,140 & 0,501 \\
\hline Top 15 & 95 & - & 105 & 12,1 & 114 & 215 & - & 0,167 & 0,502 \\
\hline
\end{tabular}

Stock Exchange Members' Share in Equity Turnover 2003 (\%)

\begin{tabular}{|l|l|l|l|l|l|l|l|l|l|}
\hline & DK & DK2 & FI & IS & NO & SE & ES & LA & LI \\
\hline Top 5 & 53 & - & 31 & 84 & 48 & 42 & 86 & 59 & 95 \\
\hline Top 10 & 71 & - & 53 & 97 & 75 & 67 & 97 & 81 & 100 \\
\hline Top 15 & 80 & - & 72 & 100 & 87 & 84 & 100 & 97 & 100 \\
\hline
\end{tabular}

*Latvia: The share is calculated on Central market volume (net of block and reported trades).

\begin{tabular}{|l|l|l|l|l|l|l|l|l|l|}
\hline $\begin{array}{l}\text { Number of Stock Ex- } \\
\text { change members at the } \\
\text { end of year } 2003\end{array}$ & 42 & 252 & 44 & 18 & 41 & 79 & 12 & 13 & 21 \\
\cline { 2 - 10 }
\end{tabular}




\section{Appendix C - The questionnaire}

\section{Questionnaire to Nordic Stock Exchanges about market efficiency}

As a follow-up to Dr. Benn Steil's report to the Nordic Council of Ministers in June 1999, please find enclosed a questionnaire to be completed. The purpose of the questionnaire is to determine the situation of the Nordic Stock Market and to collect any information and comments you would like to put forward to the Nordic Council of Ministers for further consideration.

Below you will find questions about your legal environment, foreign investment, competition and cooperation with other exchanges along with more questions about the nature of your individual market. The purpose of these questions is to create a comparison between the Nordic countries and to reveal, whether there are any inhibitions to market efficiency that need to be attended to. In an appendix there are more basic statistical questions about your Stock Exchange for reference.

This questionnaire is primarily focused on the efficiency of the Nordic Stock Market and not on derivatives or bonds which may be covered by a further questionnaire. Accordingly, please answer all questions with relation to your stock market functions. It is emphasized that answering to the questionnaire takes place on a voluntary basis. Please indicate if you prefer your answers to the questionnaire not to be published in the report to the Nordic Council of Ministers.

Please send replies to this questionnaire to the relevant member of the Nordic Council of Ministers' working group of securities markets, as specified below, by Monday 16 th of February, 2004.

Country:

Name:

Address: 


\section{Legal environment}

The purpose of the following questions is to identify, whether there are any laws or legal rules that unnecessarily hinder the efficiency of your market related to increased liquidity, increased depth of the market, decreased spreads or costs etc. In questions a) to d) below some categories of laws are mentioned that might effect market efficiency. If you identify any such laws or other needs for improvement in this field, please specify further in part e) below.

a) Are there any taxing laws that limit the efficiency of your market? Yes () / No ()

b) Are there any laws hindering foreign investment in your market? Yes ( ) / No ()

c) Are there any laws regarding pension funds that limit the efficiency of your market? $\underline{\operatorname{Yes}() / \mathrm{No}()}$

d) Are there any other laws or regulations that negatively effect the efficiency of your market? Yes ()/No ()

e) If you answered yes to any of the questions above, please identify such laws and discuss shortly their implication and/or make suggestions for improvements. 


\section{Foreign investors}

The purpose of these questions is to estimate the level of foreign access and participation in the Nordic Stock Market.

\begin{tabular}{|l|l|l|l|}
\hline $\begin{array}{l}\text { Members/ companies 31 } \\
\text { December 2003 }\end{array}$ & Nordic countries & $\begin{array}{l}\text { Other European coun- } \\
\text { tries }\end{array}$ & $\begin{array}{l}\text { Other coun- } \\
\text { tries }\end{array}$ \\
\hline $\begin{array}{l}\text { What was the number of } \\
\text { remote stock exchange } \\
\text { members in your ex- } \\
\text { change from: }\end{array}$ & & & \\
\hline $\begin{array}{l}\text { What was their \% of } \\
\text { total market turnover in } \\
2003 ?\end{array}$ & & & \\
\hline $\begin{array}{l}\text { What was the number of } \\
\text { foreign companies listed } \\
\text { in your exchange from: }\end{array}$ & & & \\
\hline $\begin{array}{l}\text { What was the number of } \\
\text { domestic companies that } \\
\text { only have a foreign list- } \\
\text { ing in: }\end{array}$ & & & \\
\hline
\end{tabular}

a) Have there been any significant changes in the accessibility of foreign investors, members and companies to your market since 1999? (If yes, please describe shortly).

b) What unnecessary domestic obstacles still remain for foreign investors to trade in domestic stock, if any? 


\section{Competition}

The purpose of the following questions is to identify, what incentives or objections the Stock Exchanges may have toward or against further integration of the Nordic Stock Market.

What geographic and/or functional area do you see as your competitive market?

a) Do you consider transparency rules, e.g. how frequently listed companies must publish their financial reports etc., to affect your competitive status positively or negatively? Please describe.

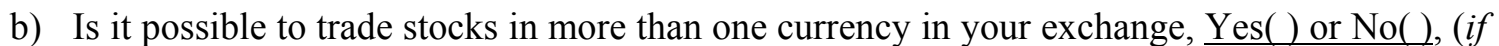
yes, which currencies: competitive status? ) and do you see that as having a major impact on your

c) Do you see any threats to your competitive status or new possibilities in the changes that are happening and will be happening in the Nordic and/or European stock markets or legislation within the next few years? 


\section{Level of cooperation with other exchanges}

The purpose of these questions is to identify the level of cooperation between the Nordic Stock Exchanges, and their cooperation with exchanges outside the Nordic region. Please fill in the following table, or provide more specific information where needed.

\begin{tabular}{|l|l|l|l|l|l|}
\hline Level of Cooperation & $\begin{array}{l}\text { Dom- } \\
\text { estic }\end{array}$ & $\begin{array}{l}\text { Nordic } \\
\text { countries }\end{array}$ & $\begin{array}{l}\text { European } \\
\text { countries }\end{array}$ & USA & $\begin{array}{l}\text { Other } \\
\text { countries }\end{array}$ \\
\hline Joint trading systems? & & & & & \\
\hline $\begin{array}{l}\text { Ownership of your exchange } \\
\text { is? }\end{array}$ & & & & & \\
\hline $\begin{array}{l}\text { Does any of the major own- } \\
\text { ers of your exchange also } \\
\text { operate or own other ex- } \\
\text { changes or related organiza- } \\
\text { tions? (specify type of or- } \\
\text { ganization) }\end{array}$ & & & & & \\
\hline Other cooperation: & & & & & \\
\hline
\end{tabular}

b) Do you expect increased cooperation or mergers, including vertical integration, within the European stock market within the next few years? (If yes, please specify in which of the above categories you expect or would like to see increased cooperation). 


\section{Clearing and Settlement}

The purpose of these questions is to clarify the basic difference between the clearing and settlement rules of the Stock Exchanges and how it affects their competitive status.

a) How do you estimate that your clearing and settlement system affects your competitive status? Is it joint $(\square$ ) or separate $(\square$ ) from the clearing and settlement systems that other stock exchanges in related markets use? Please comment on how your clearing and settlement system affects your competitive status?

What is the clearing and settlement rule on your Stock Exchange?

\begin{tabular}{|l|l|l|l|}
\hline $\mathrm{T}+1$ & $\mathrm{~T}+2$ & $\mathrm{~T}+3$ & Other? \\
\hline & & & \\
\hline
\end{tabular}

b) How does the clearing and settlement rule above affect your competitive status?

c) Please describe shortly how a foreign investor would most likely or in practice trade in your Stock Exchange. 


\section{Other}

Please provide any data, which you believe would be helpful in estimating and comparing the efficiency of your Stock Exchange. Additional information, such as a fact book for 2003 and references to any studies that may have been made recently, is warmly welcome.

Please enter other comments you wish to put forth.

\section{Contact}

Please specify a contact person for further information.

Name:

Status:

Email: Telephone: 


\section{Appendix - Basic data}

In this section please provide basic information about your Stock Exchange. Please answer only about your stock market and do not include bonds or derivatives in your figures. Please enter all figures in euros, using the rate as of 31 December 2003.

\begin{tabular}{|l|l|}
\hline Basic Data about Stock market & Figure \\
\hline Number of companies listed on 31 Dec 2003 & \\
\hline Number of new companies listed in 2003 & \\
\hline Number of companies delisted in 2003 & \\
\hline Total turnover in the year 2003 & \\
\hline Total turnover in the year 2002 & \\
\hline Turnover rate (turnover velocity) in 2003 & \\
\hline Number of trading days in 2003 & \\
\hline
\end{tabular}

\begin{tabular}{|l|l|l|l|l|l|}
\hline $\begin{array}{l}\text { Equi- } \\
\text { ty } \\
\text { Tur- } \\
\text { nover } \\
2003\end{array}$ & $\begin{array}{l}\text { Turnover } \\
\text { (specify } \\
\text { volume + } \\
\text { currency) }\end{array}$ & $\begin{array}{l}\text { Percentage } \\
\text { of total } \\
\text { stock turn- } \\
\text { over }\end{array}$ & $\begin{array}{l}\text { Market va- } \\
\text { lue 31 Dec } \\
2003\end{array}$ & $\begin{array}{l}\text { Number } \\
\text { of trades }\end{array}$ & $\begin{array}{l}\text { Turn- } \\
\text { over rate }\end{array}$ \\
\hline Top 5 & & & & & \\
\hline Top 10 & & & & & \\
\hline Top 15 & & & & & \\
\hline Total & & & & & \\
\hline $\begin{array}{l}\text { Main list (if divi- } \\
\text { ded) }\end{array}$ & & & & & \\
\hline $\begin{array}{l}\text { Secondary list(s) } \\
\text { (if divided OR if } \\
\text { separate from main } \\
\text { list?) }\end{array}$ & & & & & \\
\hline
\end{tabular}

\begin{tabular}{|l|l|l|}
\hline $\begin{array}{l}\text { Stock Exchange Members' Share in Equity } \\
\text { Turnover 2003 (market share) }\end{array}$ & Trade volume & $\begin{array}{l}\text { Percentage of } \\
\text { total trade }\end{array}$ \\
\hline Top 5 & & \\
\hline Top 10 & & \\
\hline Top 15 & & \\
\hline
\end{tabular}

What was the total number of Stock Exchange members at the end of 2003? 
Obtain your Nord and TemaNord reports from:

\author{
BELGIUM \& LUXEMBOURG \\ Jean de Lannoy \\ Avenue du Roi, 202, 1190 Brussels \\ Tel +32 (0)25385169 \\ Fax +32 (0)2538 0841 \\ jean.de.lannoy@euronet.be
}

\section{CANADA}

Renouf Publishing Company Ltd

5369 Canotek Road, Ottawa,

Ontario K1J 9J3

Tel + 1 (613) 7452665

$\mathrm{Fax}+1$ (613) 7457660

order.dept@renoufbooks.com

www.renoufbooks.com

\section{CHINA}

CNPIEC

Europe Division 16 Gongti East Road,

P.O. Box 88, Beijing

Tel +86105066 688-8

Fax +86 105063101

\section{DENMARK}

Svensk-Norsk Bogimport A/S

Esplanaden 8 B, 1263 København K

Tel +4533142666 Fax +4533143588

snb@bog.dk

www.snbog.dk

\section{ESTONIA}

Astro Raamatud AS

Pärnu mnt 142, 11317 Tallinn

Tel +372 6548485 Fax +3726548475

book@astro.ee

\section{FAROE ISLANDS}

H.N. Jacobsens Bókahandil

Postboks 55, 110 Tórshavn

Tel +298 311036 Fax +2983178 73

hnj@hnj.fo

www.hnj.fo

\section{FINLAND}

Akademiska Bokhandeln

PB 128, Centralgatan 1,

00101 Helsingfors

Tel +358 912141

akatilaus@akateeminen.com

www.akateeminen.com

\section{FRANCE}

Librairie LAVOISIER

14 , rue de Provigny,

94236 Cachan Cedex

Tel +33 (1) 47406700

Fax +33 (1) 47406702

group@lavoisier.fr

www.lavoisier.fr

\section{GERMANY}

UNO-Verlag GmbH

Am Hofgarten 10, 53113 Bonn

Tel +49 (0)228949020

$\mathrm{Fax}+49$ (0)228 9490222

info@uno-verlag.de

www.uno-verlag.de

\section{HUNGARY}

Euro Info Service

PO Box 1039, 1245 Budapest

Tel +36 (1) 3292487

Fax +36 (1) 3492053

euroinfo@euroinfo.hu

\section{ICELAND}

Mál og Menning

Laugavegi 18, 101 Reykjavik

Tel +354 (9)5152500

Fax +354 (9)515 2505

verslun@mm.is

\section{LATVIA}

Jana Rozes Gramàtnica

Kr. Barona iela 5, 1011 Riga

$\mathrm{Tel}+371(0) 2284288$

Fax +3717370922

\section{LITHUANIA}

Penki Kontinentai

A. Stulginskio 5, 2001 Vilnius

Tel +370 (5) 2664540

Fax +370 (5) 2664565

books@5ci.lt

www.books.lt

\section{NORWAY}

Akademika A/S

Postboks 84 Blindern, 0314 Oslo

Tel +4722853030 Fax +4722 853080

bloken@sio.uio.no

www.akademika.no

\section{ROMANIA}

Euromedia s.r.I.

Str Dionisie Lupu nr 65, 70184 Bucuresti

Tel + 4016140664

$\mathrm{Fax}+4013129646$

\section{SWEDEN}

Fritzes

Kundservice, 10647 Stockholm

Tel +46 (0)8 6909190

$\mathrm{Fax}+46(0) 86909191$

order.fritzes@nj.se

www.fritzes.se
THE NETHERLANDS

De Lindeboom Internationale Publicaties

M.A. de Ruyterstraat $20 \mathrm{~A}$,

NL-7482 BZ Haaksbergen

Tel +31 (0)53 5740004,

Fax +31 (0)535729296

books@delindeboom.com

www.delindeboom.com

\section{UNITED KINGDOM}

The Stationery Office

P.O. Box 276, London SW8 5DT

Tel +448706005522

Fax +44 8706005533

customer.services@tso.co.uk www.tso.co.uk/bookshop

USA

Bernan

4611-F Assembly Drive,

Lanham MD 20706-4391

Tel +1 (301) 4597666

Fax +1 (301) 4590056

query@bernan.com

www.bernan.com

\section{ÅLAND}

Lisco bok- och pappershandel

Skarpansvägen 25, Box 8 ,

22101 Mariehamn

Tel +358 (0)1817 177

Fax +358 (0)18 19771

info@lisco.fi 